Article

\title{
Environmental Benefits of Ultra-Low Emission (ULE) Technology Applied in China
}

\author{
Xiaomiao Jiao ${ }^{1,2,3}$, Ruijing $\mathrm{Ni}^{2}$, Lulu Chen ${ }^{2}$, Jamiu Adetayo Adeniran ${ }^{2,4}\left({ }^{\circ}\right.$, Hongjian Weng ${ }^{2}$, Jingxu Wang ${ }^{5}$, \\ Youfan Chen ${ }^{2,6}\left(\mathbb{D}\right.$, Shihua Ren ${ }^{1, *}$ and Xiao Liu ${ }^{3, *}$ \\ 1 Technology Support Center, China Coal Research Institute, Beijing 100013, China; jiaoxm@pku.edu.cn \\ 2 Laboratory for Climate and Ocean-Atmosphere Studies, Department of Atmospheric and Oceanic Sciences, \\ School of Physics, Peking University, Beijing 100871, China; nirj@pku.edu.cn (R.N.); \\ luluchen@pku.edu.cn (L.C.); adeniranja@pku.edu.cn (J.A.A.); wenghj@pku.edu.cn (H.W.); \\ cyfan@pku.edu.cn (Y.C.) \\ 3 National Institute of Clean-and-Low-Carbon Energy (NICE), Beijing 102211, China \\ 4 Department of Chemical Engineering, Faculty of Engineering and Technology, University of Ilorin, \\ Ilorin 240003, Nigeria \\ 5 Key Laboratory of Physical Oceanography, College of Oceanic and Atmospheric Sciences, \\ Ocean University of China, Qingdao 266100, China; wangjingxu@ouc.edu.cn \\ 6 Sichuan Academy of Environmental Policy and Planning, Chengdu 610041, China \\ * Correspondence: ren@cct.org.cn (S.R.); liuxiao.u@chnenergy.com.cn (X.L.)
}

Citation: Jiao, X.; Ni, R.; Chen, L.; Adeniran, J.A.; Weng, H.; Wang, J.;

Chen, Y.; Ren, S.; Liu, X.

Environmental Benefits of Ultra-Low Emission (ULE) Technology Applied in China. Atmosphere 2021, 12, 1693. https://doi.org/10.3390/atmos12 121693

Academic Editor: Tao Zhu

Received: 7 November 2021

Accepted: 14 December 2021

Published: 17 December 2021

Publisher's Note: MDPI stays neutral with regard to jurisdictional claims in published maps and institutional affiliations.

Copyright: (c) 2021 by the authors. Licensee MDPI, Basel, Switzerland. This article is an open access article distributed under the terms and conditions of the Creative Commons Attribution (CC BY) license (https:// creativecommons.org/licenses/by/ $4.0 /)$.

\begin{abstract}
Seven scenarios were designed to study the national environmental benefits of ULE in coal-fired power plants (CPPs), ULE in industrial coal burning (ICB) and $\mathrm{NH}_{3}$ emission reduction by using the GEOS-Chem model. The results showed that although the CPPs have achieved the ULE transformation target, the $\mathrm{PM}_{2.5}$ concentration across the country has decreased by $4.8 \%\left(1.4 \mu \mathrm{g} / \mathrm{m}^{3}\right)$. Due to the complex non-linear chemical competition mechanism among nitrate and sulfate, the average concentration of nitrate in the country has increased by $1.5 \%\left(0.1 \mu \mathrm{g} / \mathrm{m}^{3}\right)$, which has reduced the environmental benefits of the power plant emission reduction. If the ULE technology is applied to the ICB to further reduce $\mathrm{NO}_{\mathrm{x}}$ and $\mathrm{SO}_{2}$, although the $\mathrm{PM}_{2.5}$ concentration can be reduced by $10.1 \%$ $\left(2.9 \mu \mathrm{g} / \mathrm{m}^{3}\right)$, the concentration of nitrate will increase by $2.7 \%\left(0.2 \mu \mathrm{g} / \mathrm{m}^{3}\right)$. Based on the CPPs-ULE, $\mathrm{NH}_{3}$ emissions reduced by $30 \%$ and $50 \%$ can significantly reduce the concentration of ammonium and nitrate, so that the $\mathrm{PM}_{2.5}$ concentration is decreased by $11.5 \%\left(3.3 \mu \mathrm{g} / \mathrm{m}^{3}\right)$ and $16.5 \%\left(4.7 \mu \mathrm{g} / \mathrm{m}^{3}\right)$. Similarly, based on the CPPs-ICB-ULE, $\mathrm{NH}_{3}$ emissions can be reduced by $30 \%$ and $50 \%$ and the $\mathrm{PM}_{2.5}$ concentration reduced by $15.6 \%\left(4.4 \mu \mathrm{g} / \mathrm{m}^{3}\right)$ and $20.3 \%\left(5.8 \mu \mathrm{g} / \mathrm{m}^{3}\right)$. The CPPs and ICB use the ULE technology to reduce $\mathrm{NO}_{\mathrm{x}}$ and $\mathrm{SO}_{2}$, thereby reducing the concentration of ammonium and sulfate, causing the $\mathrm{PM}_{2.5}$ concentration to decline, and $\mathrm{NH}_{3}$ reduction is mainly achieved through reducing the concentration of ammonium and nitrate to reduce the concentration of $\mathrm{PM}_{2.5}$. In order to better reduce the concentration of $\mathrm{PM}_{2.5}, \mathrm{NO}_{x}, \mathrm{SO}_{2}$ and $\mathrm{NH}_{3}$ emission reduction control measures should be comprehensively considered in different regions of China. By comprehensively considering the economic cost and environmental benefits of ULE in ICB and $\mathrm{NH}_{3}$ emission reduction, an optimal haze control scheme can be determined.
\end{abstract}

Keywords: haze pollution; emission factors; ultra-low emission (ULE); GEOS-Chem model

\section{Introduction}

Haze pollution is a complex phenomenon, resulting from primary emissions from multiple sources interacting with meteorology and atmospheric photochemistry. Over the past decade, China has experienced severe haze pollution, marked by fine particulate matter (PM), especially in the Beijing-Tianjin-Hebei (BTH) regions, according to the air quality status reports released by China's Ministry of Environmental Protection [1]. Fine particulate matter smaller than $2.5 \mu \mathrm{g}\left(\mathrm{PM}_{2.5}\right)$ is particularly troublesome and has been implicated in a range of adverse health outcomes [2,3]. The annual mean $\mathrm{PM}_{2.5}$ concentration in the BTH 
region was $77 \mu \mathrm{g} / \mathrm{m}^{3}$ in 2015 (MEP., 2015), far beyond the World Health Organization's (WHO) interim target $\left(35 \mu \mathrm{g} / \mathrm{m}^{3}\right.$ ) for annual mean $\mathrm{PM}_{2.5}$ concentration and 1.20 times the secondary class standard in China's new National Ambient Air Quality Standard [4].

The high ambient $\mathrm{PM}_{2.5}$ concentration is believed to be closely related to China's large primary energy consumption, especially coal consumption. Specific pollutants emitted from coal combustion, such as $\mathrm{SO}_{2}, \mathrm{NO}_{\mathrm{x}}$ and primary $\mathrm{PM}$, have been implicated as major contributors to haze episodes in China [5]. Aimed at mitigating the severe air pollution situation, the Chinese government has issued several regulations to reduce emissions from coal combustion since 2013. The most important efforts to reduce air pollution include the installation of (ULE) technology at all coal-fired power plants (CPPs) by 2020, and these efforts have already produced measurable reductions in primary $\mathrm{NO}_{\mathrm{x}}, \mathrm{SO}_{2}$ and particulate matter (PM) emissions [6]. Regulatory policies have also been issued for coal consumption for industrial and residential use, as well as separate policies related to emissions from the transportation sector $[7,8]$. The cumulative effect of these measures is an improvement in air quality, but there still remains room for a deeper understanding of the effectiveness of different politic strategies for emission control to guide policymakers in their efforts to make further progress.

Thus far, the goal of ULE in power plants in China has been exceeded [9]. However, the concentration of $\mathrm{PM}_{2.5}$ in the atmosphere has been reduced by around $2.5 \mu \mathrm{g} / \mathrm{m}^{3}$ [10], and haze pollution is still severe. Previous studies indicate that industrial coal combustion dominates the coal consumption, with a $40 \%$ contribution to all coal consumption, followed by coal combustion in power plants and the domestic sector [11]. Thus, emissions from the industrial sector are significant contributors to ambient $\mathrm{PM}_{2.5}$ over most of China [12-14]. However, most studies have focused on exploring the environmental benefits from ULE facilities installed in coal-fired power plants (CPPs), neglecting the effects of ULE in industrial coal burning (ICB).

Here, three scenarios were designed to assess the environmental benefits of ULE technology further applied to ICB and to quantify the cumulative effects of ULE installed both in CPPs and ICB. In addition, the main source of $\mathrm{PM}_{2.5}$ is secondary inorganic aerosol (SIA), which accounts for $43.6-53.3 \%$, mainly composed of sulfate $\left(\mathrm{SO}_{4}^{2-}\right)$, nitrate $\left(\mathrm{NO}_{3}^{-}\right)$ and ammonium $\left(\mathrm{NH}_{4}^{+}\right)[15,16]$. Researchers have found that $\mathrm{NH}_{3}$ in the atmosphere plays a crucial role in the formation of sulfate and nitrate, and there is a competitive mechanism [17]. Thus, $\mathrm{NH}_{3}$ emission control is directly beneficial for reducing $\mathrm{PM}_{2.5}[18,19]$. By considering the importance of $\mathrm{NH}_{3}$ emissions, four scenarios were further conducted to quantify the environmental benefits of $\mathrm{NH}_{3}$ emission reduction on the basis of ULE applied in CPPs and ICB.

All of the scenarios are described in Section 2. Section 2 also presents the data source used in this study and the description of the GEOS-Chem model. Section 3 then provides the analysis of the results regarding the emission reduction of $\mathrm{NO}_{\mathrm{x}}$ and $\mathrm{SO}_{2}$ from all CPPs and ICB in China in 2015 in the context of the ULE levels of CPPs, updated from our previous study [20]; comparisons between the simulated results and observations to evaluate the model are shown in Section 4; Section 5 discusses the environmental benefits brought about by ULE facilities installed in $\mathrm{CPP}_{\mathrm{S}}$ and ICB, accompanied by $\mathrm{NH}_{3}$ emission reductions in different scenarios; and the last section summarizes the conclusions.

\section{Data Source, Method and Model Description}

\subsection{Data Source and Method}

The environmental benefits of using GEOS-Chem to quantify the application of ULE in CPPs and ICB are based on the data source shown in Table 1. Firstly, an emission inventory of $\mathrm{NO}_{x}, \mathrm{SO}_{2}$ and PM as air pollutants after ULE technology is applied in CPPs and ICB in China, based on reasonable assumptions, was established. Then, the environmental benefits brought about by the application of ULE technology in CPPs and ICB in China were quantified by using the GEOS-Chem model. Finally, some policy suggestions for achieving greater environmental benefits in the future were put forward. 
Table 1. Description of data used in this study.

\begin{tabular}{|c|c|c|}
\hline Data & Description & Reference \\
\hline $\begin{array}{l}\text { The emission factor of CPPs } \\
\text { that install ULE facilities }\end{array}$ & $\begin{array}{c}\text { ULE emission factors of CPPs in } \\
\text { China }\left(\mathrm{EF}_{\mathrm{SO} 2}=0.17 \mathrm{~g} / \mathrm{Kg}\right. \\
\mathrm{EF}_{\mathrm{NO} x}=0.41 \mathrm{~g} / \mathrm{Kg} \\
\left.\mathrm{EF}_{\mathrm{PM}}=0.03 \mathrm{~g} / \mathrm{Kg}\right)\end{array}$ & Liu et al., (2019) [20] \\
\hline Coal consumption data & $\begin{array}{l}\text { Raw coal consumption in power } \\
\text { plants and industries in different } \\
\text { provinces in } 2015 \text { (detailed } \\
\text { classification of the power and } \\
\text { industrial sectors is listed in Table S1). }\end{array}$ & $\begin{array}{c}\text { China Energy Statistics } \\
\text { Yearbook [21] }\end{array}$ \\
\hline $\begin{array}{l}\text { Multi-Resolution Emission } \\
\text { Inventory for China (MEIC) }\end{array}$ & $\begin{array}{l}\text { The MEIC data on spatial distribution } \\
\text { and seasonal variation of pollutants } \\
\text { as well as total } \mathrm{NO}_{x}, \mathrm{SO}_{2}, \mathrm{PM} \\
\text { emissions from power plants and } \\
\text { industrial sectors were used. }\end{array}$ & MEIC $[7,22]$ \\
\hline $\begin{array}{l}\text { Greenhouse Gas and Air } \\
\text { Pollution Interactions and } \\
\text { Synergies (GAINS) }\end{array}$ & $\begin{array}{l}\text { The GAINS inventory provides } \\
\text { provincial-level emission data for } 11 \\
\text { detailed sectors (details are listed in } \\
\text { Table S2). The GAINS data on } \\
\text { pollutant emissions from different } \\
\text { fuel types in the power sector and } \\
\text { industrial combustion and industrial } \\
\text { processes and production in the } \\
\text { industrial sector were used. }\end{array}$ & GAINS $[23,24]$ \\
\hline
\end{tabular}

In order to establish the emissions inventory of air pollutants by using ULE technology in CPPs, the emission factors of air pollutants after ULE technology are used in CPPs were ensured to be consistent with Liu et al.'s research results [20], which updated the emission factors of ULE technology applied in CPPs in China, and according to the national energy statistics yearbook [21], to obtain the coal consumption data of different provinces. Only $\mathrm{NO}_{\mathrm{x}}, \mathrm{SO}_{2}$ and $\mathrm{PM}$ pollutant emissions were considered, when estimating the emissions after the ULE technology was applied to the CPPs in China, given the limited data availability for the emission factor of CPPs that install ULE facilities.

The application of GEOS-Chem to quantify the environmental benefits in different scenarios is based on MEIC emission data and the corresponding spatial distribution. In order to quantify the environmental benefits brought about by the application of ULE technology in the CPPs and ICB, the total emissions from the power and industry sectors provided by MEIC were used. However, the total emissions from the power and industry sectors include not only coal combustion emissions but also other emissions (oil, gas and others); MEIC does not provide these detailed data. Due to the data limitations, the proportion of coal combustion and non-coal combustion obtained from GAINS was used. Moreover, we assumed that the proportion of emissions from coal combustion and non-coal combustion in the power and industry sectors on the MEIC was the same as the proportion of emissions from coal combustion and non-coal combustion in the power and industry sectors on the GAINS.

\subsection{Simulation Scenario Design}

\subsubsection{Emissions Calculation}

The emission of each species $\left(\mathrm{NO}_{x}, \mathrm{SO}_{2}\right.$ and PM) from CPPs after applying the ULE technology can be calculated as:

$$
E_{C P P S}=W_{S} \times E F_{U L E}
$$


Here, $E F_{U L E}$ is the emission factor after the ULE technology is applied in the CPP; $W_{S}$ is the standard coal consumption in the CPP. Since raw coal consumption is recorded in the yearbook, the standard coal consumption was converted:

$$
W_{S}=W_{R} \times Q_{R} / Q_{S}
$$

Here, $Q_{S}$ is the lower heating value for standard coal $(29,307.6 \mathrm{~J} / \mathrm{kg}), Q_{R}$ is the lower heating value for raw coal (defined by the type of coal), and $W_{R}$ is the raw coal consumption by mass.

$$
P_{C M}=P_{C G}=E_{C G} / E_{G}
$$

Here, $P_{C M}, P_{C G}$ is the proportion of pollutants emitted by CPPs in the total emissions in MEIC and GAINS, respectively; $E_{C G}$ is the amount of pollutants emitted by CPPs in GAINS; $E_{G}$ is the total pollutant emissions from the power sector in GAINS.

Thus, we can determine the pollutant emission amount of the power sector after ULE technology is applied in CPPs:

$$
E_{P}=E_{C P P_{s}}+\left(1-P_{C M}\right) \times E_{M}
$$

Similarly, we assumed that ULE technology can be used in ICB and achieve the same emission level as CPPs. Therefore, the emission can be obtained after the application of ULE technology in ICB, based on a similar calculation method. It is also assumed that the proportion of emissions from ICB in the industry sector on the MEIC is the same as the proportion of emissions from ICB in the industry sector on the GAINS, and the GAINS provides detailed data of pollutant classification emissions.

Finally, the new emission inventory is obtained after the application of the ULE technology in CPPs and ICB. The difference between the new emission and MEIC inventory is that it reveals the emission reduction of $\mathrm{NO}_{x}, \mathrm{SO}_{2}$ and $\mathrm{PM}$ after applying ULE technology in CPPs and ICB. The emission reduction ratio of different pollutants after the application of ULE technology in CPPs and ICB can be obtained as follows:

$$
R=1-E_{U L E} / E_{M}
$$

Here, $R$ is the emission reduction ratio; $E_{U L E}$ is the total pollutant emissions of the new emission inventory.

\subsubsection{Scenario Design}

Seven simulation scenarios were designed by using the GEOS-Chem model to computationally estimate the environmental benefits of the application of ULE technology in CCPs and ICB, which are listed in Table 2. All scenarios used the spatial distribution and seasonal variation of the MEIC emission inventory, and we assumed the same meteorological field as the STD scenario to minimize the impact of weather effects. The period for these simulations was 16 December 2014 to 31 January 2015. December 2014 was used as the spin-up period to eliminate the influence of initial conditions. The simulations predicted the daily concentrations of $\mathrm{PM}_{2.5}$, sulfate, nitrate and ammonium. The average values for each of these components were computed using data from 1 January 2015 to 31 January 2015. January was selected as it is the most polluted month and can best reflect the environmental benefits brought about by ULE emission reduction. 
Table 2. Summary of simulation scenarios.

\begin{tabular}{|c|c|c|c|c|}
\hline \multirow{2}{*}{ Scenarios } & \multirow{2}{*}{ Scenario Description } & \multicolumn{3}{|c|}{ Description } \\
\hline & & Power & Industry & $\mathrm{NH}_{3}$ \\
\hline STD & The standard scenario & & & \\
\hline CPPs-ULE & ULE assembled in coal-fired power plants over China. & ULE & & \\
\hline CPPs-ICB-ULE & $\begin{array}{l}\text { ULE assembled in coal-fired power plants and industrial } \\
\text { boilers over China. }\end{array}$ & ULE & ULE & \\
\hline CPPs-ULE-NH ${ }_{3}-30 \%$ & $\begin{array}{l}\text { ULE assembled in coal-fired power plants with } \mathrm{NH}_{3} \\
\text { reduced by } 30 \% \text { over China. }\end{array}$ & ULE & & $\begin{array}{c}\text { Reduced by } \\
30 \%\end{array}$ \\
\hline CPPs-ULE-NH $3-50 \%$ & $\begin{array}{l}\text { ULE assembled in coal-fired power plants with } \mathrm{NH}_{3} \\
\text { reduced by } 50 \% \text { over China. }\end{array}$ & ULE & & $\begin{array}{l}\text { Reduced by } \\
50 \%\end{array}$ \\
\hline CPPs-ICB-ULE-NH ${ }_{3}-30 \%$ & $\begin{array}{l}\text { ULE assembled in coal-fired power plants and industrial } \\
\text { boilers with } \mathrm{NH}_{3} \text { reduced by } 30 \% \text { over China. }\end{array}$ & ULE & ULE & $\begin{array}{l}\text { Reduced by } \\
30 \%\end{array}$ \\
\hline CPPs-ICB-ULE-NH $3-50 \%$ & $\begin{array}{l}\text { ULE assembled in coal-fired power plants and industrial } \\
\text { boilers with } \mathrm{NH}_{3} \text { reduced by } 50 \% \text { over China. }\end{array}$ & ULE & ULE & $\begin{array}{l}\text { Reduced by } \\
50 \%\end{array}$ \\
\hline
\end{tabular}

The standard scenario (STD) is based on the situations before implementing ULE facilities in January 2015. The remaining situations cover different scenarios of interest. The CPPs-ULE scenario assumes that all of China's CPPs have been retrofitted for ULE. The CPPs-ICB-ULE scenario assumes that the ICB process reaches the same emission level as that in the CPPs. The other four scenarios are used to further assess the environmental benefits of $\mathrm{NH}_{3}$ emission reduction based on the CPPs-ULE scenario and CPPs-ICB-ULE scenario at a national level. $\mathrm{NH}_{3}$ emission reduction refers to the total emission reduction of industries, residents, transportation and agriculture. The ammonia emission model $\left(\mathrm{PKU}-\mathrm{NH}_{3}\right)$ used in the study has been proven to accurately describe the spatial distribution and seasonal characteristics of $\mathrm{NH}_{3}$ emissions in China $[18,25]$, and to simulate the changes in secondary inorganic aerosols in atmospheric chemical transmission models [26]. Regarding China's agricultural production, the excessive use of nitrogen fertilizer and extensive animal husbandry caused by $\mathrm{NH}_{3}$ accounted for $80 \%$ of the country's total emissions, based on $\mathrm{PKU}_{-\mathrm{NH}_{3}}$ model estimates, through the peak nitrogen fertilizer emissions during the growing season (spring and summer) to implement reasonable fertilization (i.e., avoid excessive fertilization and the implementation of deep fertilizer) and so on; optimizing agricultural management can achieve an $\mathrm{NH}_{3}$ emission reduction of $50 \%$ [18]. In the field of livestock manure management, promoting the optimization of animal and poultry manure management, such as reducing the surface area and exposure time of the waste in the house, covered storage, low protein feeding and deep burial of feces at the depth of cultivated land, can significantly reduce $\mathrm{NH}_{3}$ emissions $[27,28]$. If agriculture and animal husbandry take concerted measures to control $\mathrm{NH}_{3}$ emissions, China's $\mathrm{NH}_{3}$ emissions can reach more than $50 \%$; therefore, this study selected $\mathrm{NH}_{3}$ emission reductions of $30 \%$ and $50 \%$ to explore the potential environmental benefits.

\subsection{Model Description and Sensitivity Tests}

To assess the impacts of the emission reduction brought about by applying ULE facilities in CPPs and CIB on the ambient $\mathrm{PM}_{2.5}$ concentration, several simulations using the GEOS-Chem (version 11-01) chemical transport model were conducted. To obtain more accurate results, the GEOS-Chem nested model at a high resolution of $0.25^{\circ}$ latitude $\times 0.3125^{\circ}$ longitude was used. Boundary conditions needed by the nested model were derived from the global atmospheric chemical model with a resolution of $2^{\circ}$ latitude $\times 2.5^{\circ}$ longitude every $3 \mathrm{~h}$. Both the nested model and global model are driven by the GEOS-FP meteorology fields, which is from the National Aeronautics and Space Administration (NASA) Global Modeling Assimilation Office. Both models have 47 layers in the vertical direction, and the lowest 10 layers are almost 130 thick. Model convection is parameterized by the relaxed Arakawa-Schubert scheme [29] and the vertical mixing scheme in the planetary boundary layer employs a non-local scheme implemented by Lin and McElroy (2010) [30]. 
All simulations were run with the full chemistry mechanism (Ox-NOx-CO-VOC-HO and aerosols, which include secondary inorganic aerosols (SIOA, including sulfate, nitrate and ammonium), black carbon (BC), primary organic carbon (POA), dust and sea salts, were calculated online. Modifications of the full chemistry mechanism followed Ni et al., (2018) [31]. The ammonium-sulfate-nitrate aerosol system, which uses the ISORROPIA II thermodynamic equilibrium model [32] to simulate SIOA, was coupled to the full chemistry mechanism and implemented in GEOS-Chem [33]. The parameterization of heterogeneous aerosol chemistry was treated as uptake coefficients [34]. Mineral dust aerosols were calculated online by the DEAD scheme [35] and the implementation of sea salt aerosol parameterization followed Jaegle et al., (2011) [36]. In addition to natural dust aerosols, anthropogenic sources of dust have been verified to play an important role in the total $\mathrm{PM}_{2.5}$ concentration over China. Thus, the contribution of anthropogenic dust emissions was explicitly considered by adding the gridded monthly PM emission inventory from MEIC into GEOS-Chem.

Compared to observations, standard GEOS-Chem tends to underestimate the ambient concentration of sulfate due to the simplified sulfate production mechanism implemented in the model $[37,38]$. The standard GEOS-Chem model simulates sulfate production by considering the gas-phase oxidation of $\mathrm{SO}_{2}$ by $\mathrm{OH}$ [39] and the aqueous-phase oxidation of $\mathrm{S}(\mathrm{IV})$ (including dissolved $\mathrm{SO}_{4}{ }^{2-}, \mathrm{HSO}_{3}{ }^{-}$and $\mathrm{SO}_{3}{ }^{2-}$ ) by hydrogen peroxide $\left(\mathrm{H}_{2} \mathrm{O}_{2}\right)$ and ozone $\left(\mathrm{O}_{3}\right)$ in cloud droplets. To comprehensively present the process of sulfate production, Wang et al., (2014) [40] and Zhang et al., (2015) [41] assessed the heterogeneous uptake of $\mathrm{SO}_{2}$ on the surface of deliquesced aerosols under high relative humidity conditions and the mechanism of the aqueous-phase oxidation of S(IV) by dissolved nitrogen dioxide $\left(\mathrm{NO}_{2}\right)$ in cloud droplets and aerosols with high relative humidity was followed. In addition, primary sulfate emissions are also important, accounting for 3.1\% of the total Chinese anthropogenic sulfur emissions. The share of primary sulfate emissions over China could be underestimated; thus, the contribution was increased to $4.5 \%$. These updates are welldocumented and are believed to bring the model predictions into closer agreement with measurements, especially for the winter months.

Global anthropogenic emissions were taken from EDGAR v4.2, with regional emissions overwritten by regional inventories such as the MIX Asian emission inventory over Asia [42], EMEP over Europe and NEI2011 over the US. Anthropogenic emissions over China of the standard scenario were taken from MEIC, except $\mathrm{NH}_{3}$ emissions, which were from $\mathrm{PKU}_{-\mathrm{NH}_{3}}$ [18]. Gridded monthly anthropogenic emissions for simulations conducted for other scenarios were customized and are summarized in Table 2. Parameterization of soil $\mathrm{NO}_{x}$ emissions followed Hudman et al., (2012) [43]. Biomass burning emissions were taken from the Global Fire Emission Database version 4 (GFED v4) [44]. Biogenic non-methane volatile organic compound (NMVOC) emissions were calculated online by using the Model of Emissions of Gases and Aerosols from Nature version 2.1 (MEGAN v2.1) [45]. The model simulation results with hourly ground $\mathrm{PM}_{2.5}$ concentration observation data were verified and evaluated, which concluded that the improved model used in this study can better calculate the concentration and spatial distribution of $\mathrm{PM}_{2.5}$ in China on the whole, which also indicates that this model can be used for subsequent simulation studies [46].

\section{Pollutant Reduction Potential}

Before analyzing the environmental benefits of the application of ULE technology in CCPs and ICB by using GEOS-Chem, the pollutant reduction potential of ULE technology application in CPPs and ICB was analyzed. Based on MEIC, the total national $\mathrm{NO}_{x}$ and $\mathrm{SO}_{2}$ emissions in 2015 were calculated as $23.7 \mathrm{Tg}$ and $18.2 \mathrm{Tg}$, respectively (Figure 1). Among them, the amounts of $\mathrm{NO}_{\mathrm{x}}$ and $\mathrm{SO}_{2}$ emitted by the power sector were $5.1 \mathrm{Tg}$ and $4.0 \mathrm{Tg}$, representing $21.5 \%$ and $21.9 \%$, respectively; the amounts of $\mathrm{NO}_{\mathrm{x}}$ and $\mathrm{SO}_{2}$ emitted by the industrial sector were $9.7 \mathrm{Tg}$ and $11.0 \mathrm{Tg}$, representing $40.9 \%$ and $60.4 \%$, respectively. The ULE of CPPs in China (CHN) can reduce the $\mathrm{NO}_{x}$ and $\mathrm{SO}_{2}$ of CPPs 
themselves by $87.0 \%$ and $93.3 \%$, while the emission reduction of the whole power plant sector is $83.3 \%$ and $91.6 \%$, accounting for $17.9 \%$ and $20.0 \%$ of the total $\mathrm{NO}_{\mathrm{x}}$ and $\mathrm{SO}_{2}$ emissions, respectively. If ULE facilities are installed both in CPPs and ICB, the total $\mathrm{NO}_{\mathrm{x}}$ and $\mathrm{SO}_{2}$ can be reduced by $34.2 \%(8.1 \mathrm{Tg})$ and $51.0 \%(9.3 \mathrm{Tg})$, respectively. Due to the differences in the industrial structure of coal-based energy in various provinces and regions, under the CPPs-ULE and CPPs-ICB-ULE scenarios, the emission reductions of $\mathrm{NO}_{\mathrm{x}}$ and $\mathrm{SO}_{2}$ are different. Environmental benefits are brought about by the reduction of $\mathrm{NO}_{\mathrm{x}}$ and $\mathrm{SO}_{2}$ in regions such as Beijing-Tianjin-Hebei (BTH), the Yangtze River Delta (YRD), the Sichuan-Chongqing Economic Circle (SCC) and the Pearl River Delta (PRD), etc., from the promotion of ULE technology nationwide.

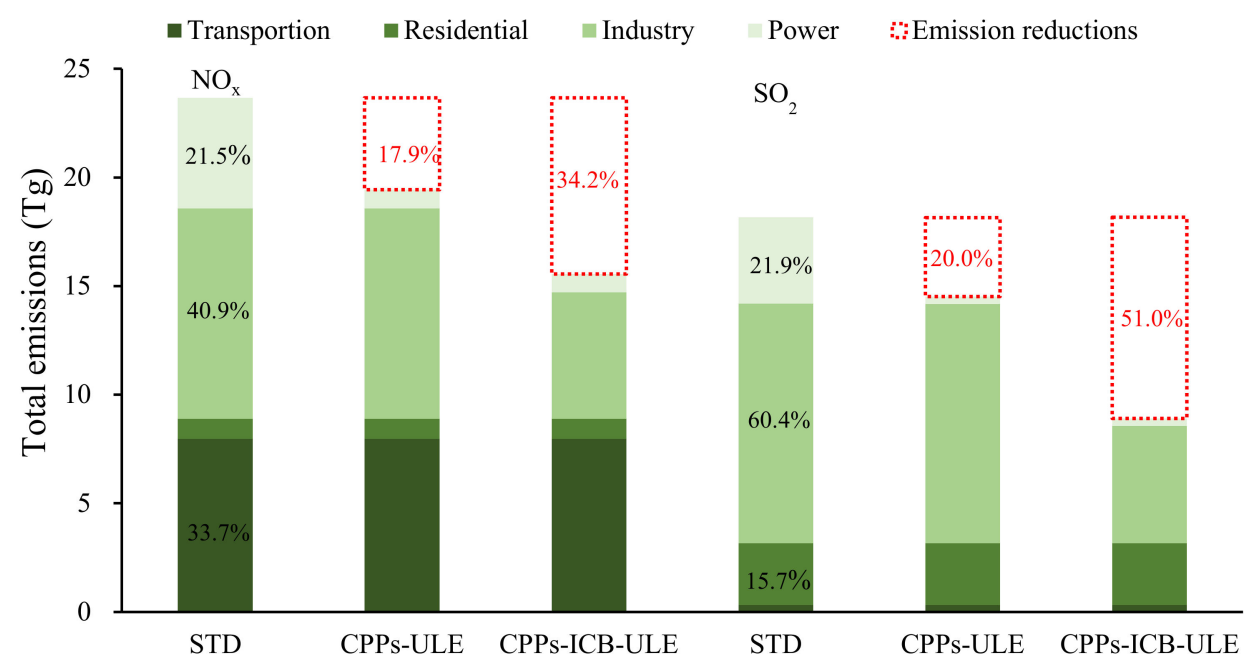

Figure 1. The total emissions of $\mathrm{NO}_{x}$ and $\mathrm{SO}_{2}$ under different scenarios and the reduction ratio relative to the STD scenario.

\subsection{Regional Sector Emission Reduction}

The reduction ratios of $\mathrm{NO}_{\mathrm{x}}$ and $\mathrm{SO}_{2}$ in the power industry and the total of different regions under different scenarios are shown in Figure 2. The ICB-ULE refers to the realization of ULE transformation in the ICB process, which was only used to calculate the pollutant reduction and does not quantify the corresponding environmental benefits separately.

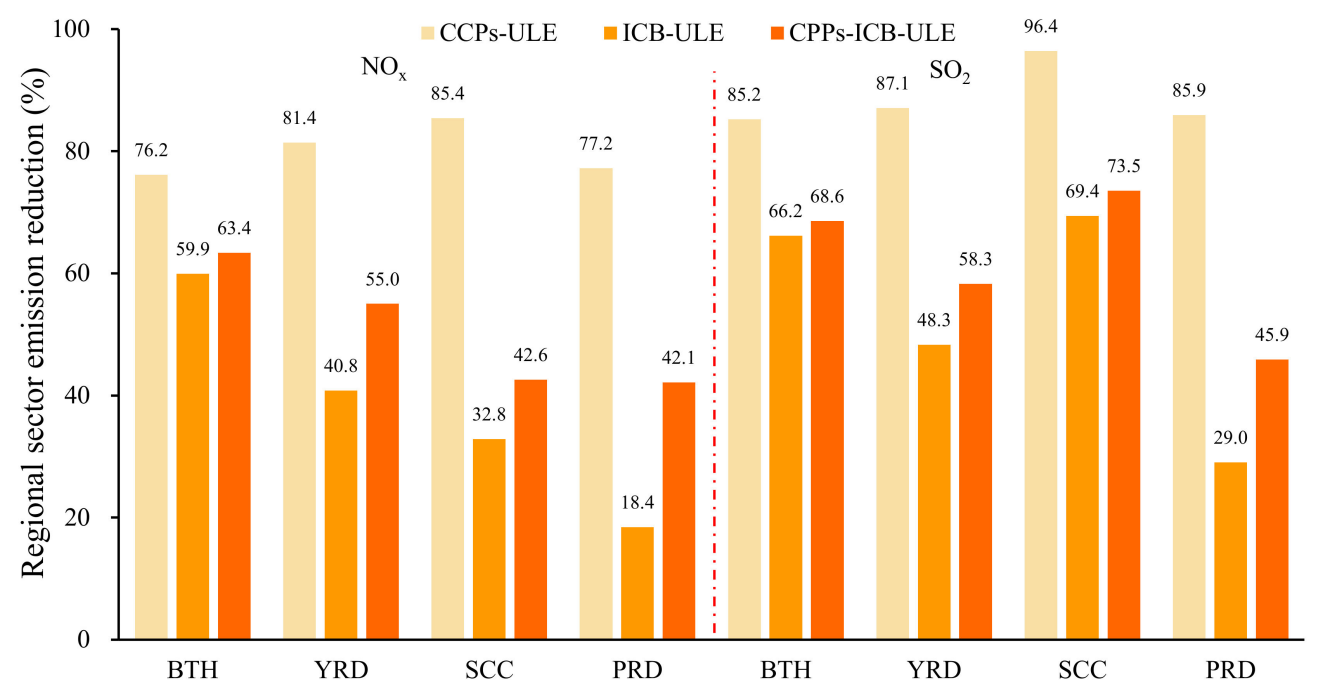

Figure 2. The reduction ratios of $\mathrm{NO}_{\mathrm{x}}$ and $\mathrm{SO}_{2}$ emissions in different regions under different scenarios.

As shown in Figure 2, under the CPPs-ULE scenario, the $\mathrm{NO}_{\mathrm{x}}$ and $\mathrm{SO}_{2}$ emission reductions in the power sector in BTH, YRD, SCC and PRD reached 76.2\%, 81.4\%, 85.4\%, 
$77.2 \%$ and $85.2 \%, 87.1 \%, 96.4 \%, 85.9 \%$, respectively. It can be seen that the emissions of CPPs account for an absolute proportion of the emissions of the power sector, and the ULE of CPPs has greatly reduced the emissions of $\mathrm{NO}_{x}$ and $\mathrm{SO}_{2}$ from the power plants. The larger the reduction ratio of $\mathrm{NO}_{\mathrm{x}}$ and $\mathrm{SO}_{2}$ in the power sector, the more urgent it is to promote the ULE transformation, and the more significant the environmental benefits will be. Under the ICB-ULE scenario, the $\mathrm{NO}_{\mathrm{x}}$ and $\mathrm{SO}_{2}$ emission reductions of the industrial sectors in BTH, YRD, SCC and PRD reach 59.9\%, 40.8\%, 32.8\%, 18.4\% and 66.2\%, 48.3\%, 69.4\%, 29.0\%, respectively. The difference in the emission reduction ratio of $\mathrm{NO}_{x}$ and $\mathrm{SO}_{2}$ reflects the difference in industrial structure. For BTH, the emission reduction ratio is as high as $60 \%$, indicating that the ICB emissions occupy a dominant position, while for PRD, the emission reduction ratio is less than $1 / 3$, indicating that the ICB emissions occupy a relatively small proportion in the industrial structure. The emission reductions of $\mathrm{NO}_{\mathrm{x}}$ and $\mathrm{SO}_{2}$ in the power and industrial sectors of BTH, YRD, SCC and PRD reach 64.3\%, 55.0\%, 42.6\%, 42.1\% and $68.6 \%, 58.3 \%, 73.5 \%, 45.9 \%$, respectively, under the CPPs-ICB-ULE scenario.

\subsection{Regional Emission Reduction}

The reduction ratios of $\mathrm{NO}_{\mathrm{x}}$ and $\mathrm{SO}_{2}$ in different regions under different scenarios are shown in Figure 3.

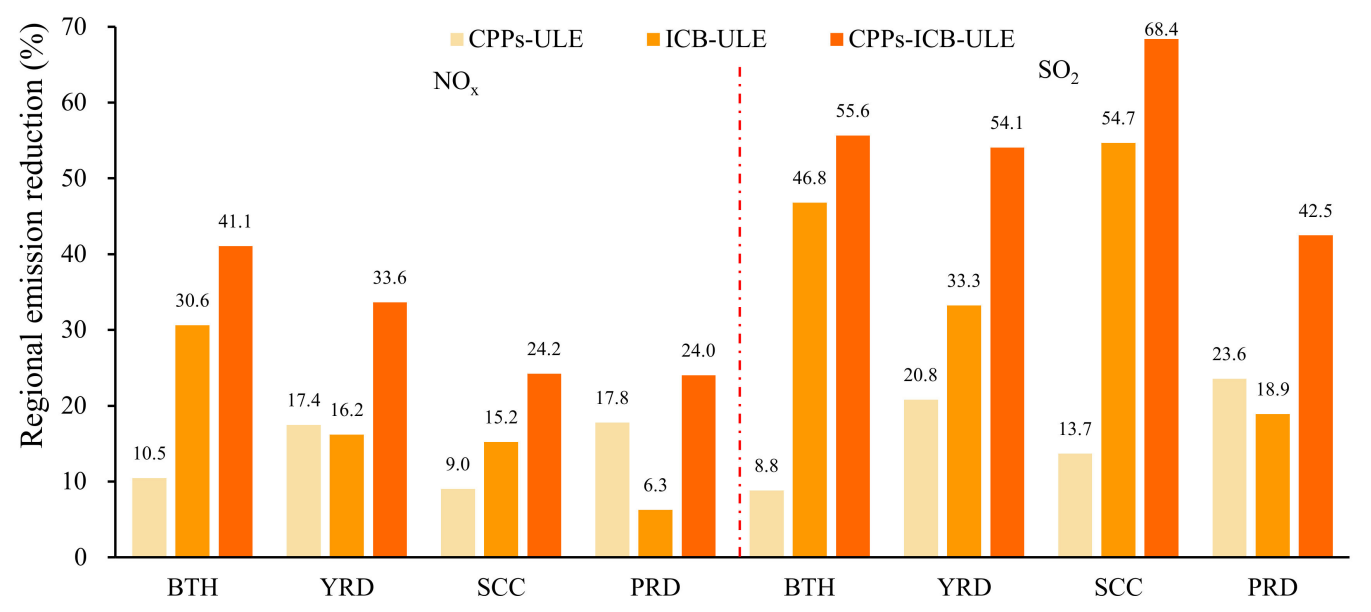

Figure 3. The reduction ratios of $\mathrm{NO}_{\mathrm{x}}$ and $\mathrm{SO}_{2}$ emissions in different regions under different scenarios.

As shown in Figure 3, under the CPPs-ULE scenario, the $\mathrm{NO}_{\mathrm{x}}$ and $\mathrm{SO}_{2}$ emission reductions of the BTH, YRD, SCC and PRD regions reached 10.5\%, 17.4\%, 9.0\%, 17.8\% and $8.8 \%, 20.8 \%, 13.7 \%, 23.6 \%$, respectively, in total $\mathrm{NO}_{\mathrm{x}}$ and $\mathrm{SO}_{2}$ emissions in each region. It can be seen that the ULE of CPPs in the BTH and YRD region reduced the total $\mathrm{NO}_{\mathrm{x}}$ and $\mathrm{SO}_{2}$ emissions in the region by around $10 \%$, while the emission reduction of CPPs in the SCC and PRD region reduced the total $\mathrm{NO}_{x}$ and $\mathrm{SO}_{2}$ emissions by around $20 \%$. Under the ICB-ULE scenario, the emission reductions of $\mathrm{NO}_{\mathrm{x}}$ and $\mathrm{SO}_{2}$ in the industrial sectors of $\mathrm{BTH}$, YRD, SCC and PRD reached 30.6\%, 16.2\%, 15.2\%, 6.3\% and 46.8\%, 33.3\%, 54.7\%, 18.9\%, respectively, in total $\mathrm{NO}_{x}$ and $\mathrm{SO}_{2}$ emissions in each region. Under the CPPs-ICB-ULE scenario, the emission reductions of $\mathrm{NO}_{x}$ and $\mathrm{SO}_{2}$ of BTH, YRD, SCC and PRD reached $41.1 \%, 33.6 \%, 24.2 \%, 24.0 \%$ and $55.6 \%, 54.1 \%, 68.4,42.5 \%$, respectively, in total $\mathrm{NO}_{\mathrm{x}}$ and $\mathrm{SO}_{2}$ emissions in each region.

For the BTH region, the $\mathrm{NO}_{x}$ and $\mathrm{SO}_{2}$ emission reduction ratios for ICB-ULE are 2.9 and 5.3 times higher than CPPs-ULE, indicating that ICB-ULE in this region can significantly reduce pollutant emissions. For the YRD region, the $\mathrm{NO}_{\mathrm{x}}$ and $\mathrm{SO}_{2}$ emission reduction ratios for ICB-ULE are 0.9 and 1.6 times those of the CPPs-ULE. For the SCC region, the $\mathrm{NO}_{x}$ and $\mathrm{SO}_{2}$ emission reduction ratios for ICB-ULE are 1.7 and 4.0 times higher than CPPs-ULE. For the PRD region, the $\mathrm{NO}_{\mathrm{x}}$ and $\mathrm{SO}_{2}$ emission reduction ratios for ICB-ULE are 1.7 and 4.0 times higher than CPPs-ULE. For the PRD region, the $\mathrm{NO}_{\mathrm{x}}$ and 
$\mathrm{SO}_{2}$ emission reduction ratios for ICB-ULE are 0.4 and 0.8 times those of the CPPs-ULE, indicating that the different emission reduction ratios of various regions are determined by differences in the energy industry structure.

\section{Environmental Benefits of ULE}

\subsection{Benefits of Primary Pollutant Emission Reduction}

The spatial distribution of the concentrations of the primary pollutants, $\mathrm{NO}_{\mathrm{x}}$ and $\mathrm{SO}_{2}$, under different scenarios based on GEOS-Chem simulation is shown in Figure 4.
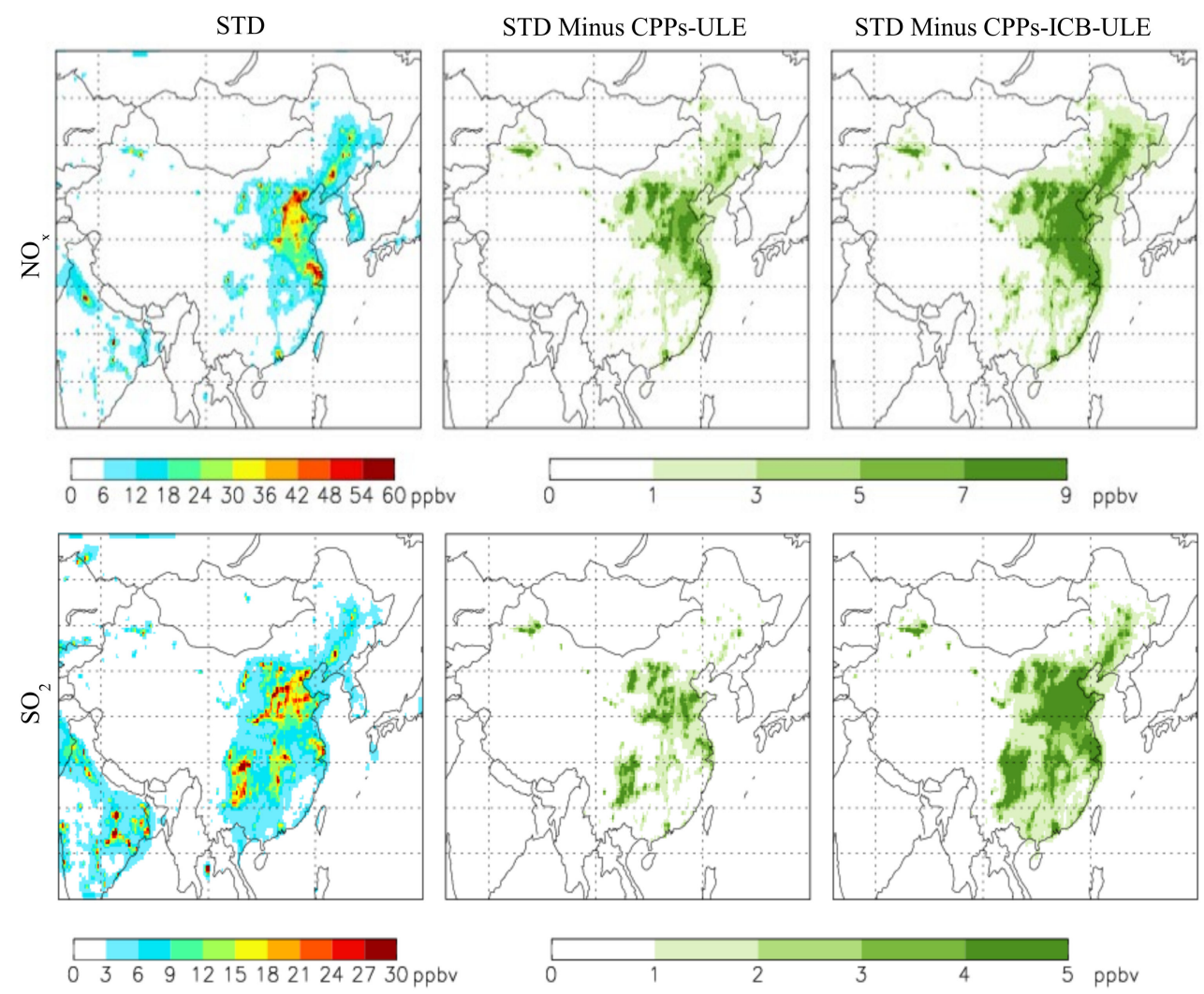

Figure 4. GEOS-Chem simulation results for distributions of primary pollutants, $\mathrm{NO}_{\mathrm{x}}$ and $\mathrm{SO}_{2}$. The concentrations of (ppbv) $\mathrm{NO}_{\mathrm{x}}$ and $\mathrm{SO}_{2}$ in the atmospheric surface layer under two scenarios.

Figure 4 shows that under the STD scenario, the average $\mathrm{NO}_{x}$ concentration in January 2015 in the North China Plain and the Yangtze River Delta was as high as 42-60 ppbv. Over other densely populated regions in Eastern China, the concentration of $\mathrm{NO}_{\mathrm{x}}$ was 6-24 ppbv, while, in the central and western regions of China, due to the relatively weak human activities, the emission of $\mathrm{NO}_{\mathrm{x}}$ was relatively low. This concentration was also very low, only $0.5-6 \mathrm{ppbv}$. The spatial distribution of the $\mathrm{SO}_{2}$ concentration was slightly different from that of $\mathrm{NO}_{\mathrm{x}}$. The difference lies in the high $\mathrm{SO}_{2}$ concentration of 15-30 ppbv in Chongqing, Guizhou and Hunan province, which is caused by the energy structure. Under the CPPs-ULE scenario, the $\mathrm{NO}_{\mathrm{x}}$ and $\mathrm{SO}_{2}$ emission reductions are mainly concentrated in high-value regions, and CPPs-ICB-ULE reduces the $\mathrm{NO}_{\mathrm{x}}$ and $\mathrm{SO}_{2}$ emissions more significantly than CPPs-ULE. Figure 5 shows the changes in the average concentrations of $\mathrm{NO}_{\mathrm{x}}$ and $\mathrm{SO}_{2}$ in different regions under different scenarios.

It can be seen from Figure 5 that, under the CPPs-ULE and CPPs-ICB-ULE scenarios, the concentration of $\mathrm{NO}_{\mathrm{x}}$ in the $\mathrm{BTH}$ region decreased from $24.9 \mathrm{ppbv}$ to $20.7 \mathrm{ppbv}$ and $13.5 \mathrm{ppbv}$, a decrease of $17.1 \%$ and $45.9 \%$, respectively, while the concentration of $\mathrm{SO}_{2}$ was reduced from $11.4 \mathrm{ppbv}$ to $10.2 \mathrm{ppbv}$ and $6.5 \mathrm{ppbv}$, a decrease of $10.7 \%$ and $42.7 \%$, respectively, compared with the STD scenario. Similarly, the concentration of $\mathrm{NO}_{x}$ in the YRD region was reduced from $19.9 \mathrm{ppbv}$ to $14.9 \mathrm{ppbv}$ and $11.9 \mathrm{ppbv}$, a decrease of $25.2 \%$ and $40.1 \%$, and the concentration of $\mathrm{SO}_{2}$ was decreased from $7.7 \mathrm{ppbv}$ to $6.0 \mathrm{ppbv}$ and $3.8 \mathrm{ppbv}$, 
a decrease of $22.0 \%$ and $51.0 \%$, respectively. The concentration of $\mathrm{NO}_{\mathrm{x}}$ in the SCC region decreased from $4.6 \mathrm{ppbv}$ to $3.8 \mathrm{ppbv}$ and $3.3 \mathrm{ppbv}$, a decrease of $25.2 \%$ and $40.1 \%$, and the concentration of $\mathrm{SO}_{2}$ decreased from $8.9 \mathrm{ppbv}$ to $7.3 \mathrm{ppbv}$ and $4.8 \mathrm{ppbv}$, a decrease of $18.6 \%$ and $45.9 \%$, respectively. The concentration of $\mathrm{NO}_{\mathrm{x}}$ in the PRD region was reduced from 6.8 ppbv to $5.3 \mathrm{ppbv}$ and $4.6 \mathrm{ppbv}$, a reduction of $23.0 \%$ and $33.1 \%$, and the concentration of $\mathrm{SO}_{2}$ was reduced from $4.0 \mathrm{ppbv}$ to $3.1 \mathrm{ppbv}$ and $2.0 \mathrm{ppbv}$, a reduction of $23.0 \%$ and $49.4 \%$, respectively. The concentration of $\mathrm{NO}_{\mathrm{x}}$ in the $\mathrm{CHN}$ region was reduced from $5.0 \mathrm{ppbv}$ to $3.8 \mathrm{ppbv}$ and $3.0 \mathrm{ppbv}$, a decrease of $24.7 \%$ and $39.8 \%$, and the concentration of $\mathrm{SO}_{2}$ was reduced from $3.6 \mathrm{ppbv}$ to $2.9 \mathrm{ppbv}$ and $2.2 \mathrm{ppbv}$, a decrease of $18.4 \%$ and $40.0 \%$, respectively. By comparison with the actual emission reductions of $\mathrm{NO}_{\mathrm{x}}$ and $\mathrm{SO}_{2}$ in the different regions in Figures 1 and 3, it can be seen that the emission reduction ratio of primary pollutants $\mathrm{NO}_{\mathrm{x}}$ and $\mathrm{SO}_{2}$ is not consistent with the actual emission reduction ratio. For example, in the CPPs-ULE and CPPs-ICB-ULE scenarios, the actual $\mathrm{NO}_{\mathrm{x}}$ and $\mathrm{SO}_{2}$ emission reduction ratios corresponding to $\mathrm{BTH}$ are $10.5 \%, 41.1 \%, 8.8 \%$ and $55.6 \%$, while the corresponding primary pollutant emission reduction ratios are $17.1 \%, 45.9 \%, 10.7 \%$ and $42.7 \%$, which is mainly because the actual $\mathrm{NO}_{\mathrm{x}}$ and $\mathrm{SO}_{2}$ emitted into the atmosphere is also affected by atmospheric transport [47]. It is also affected by complex atmospheric chemical reactions $[48,49]$.

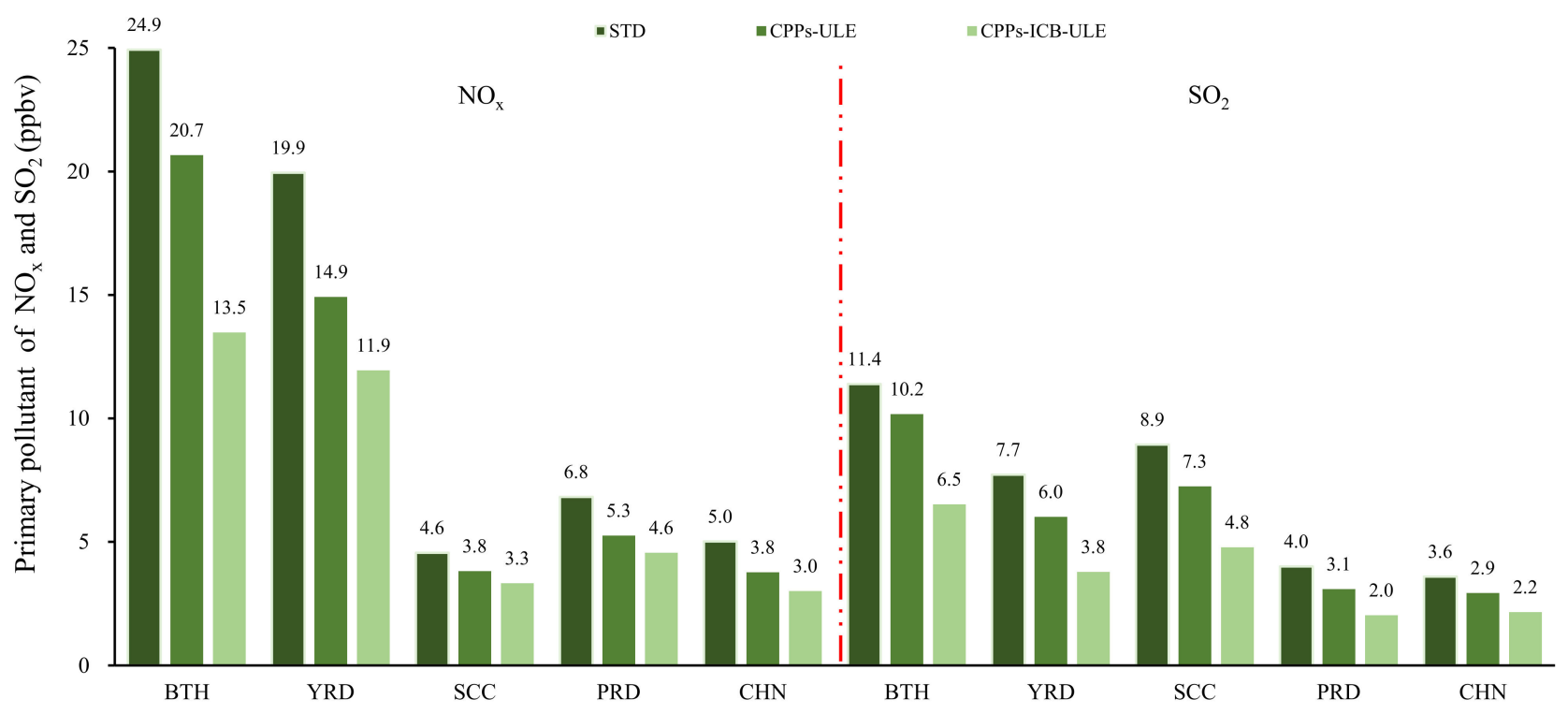

Figure 5. The reduction ratio of $\mathrm{NO}_{\mathrm{x}}$ and $\mathrm{SO}_{2}$ emissions in different regions under different scenarios.

\subsection{Benefits of Secondary Pollutant Emission Reduction}

The spatial distribution of the concentrations of the secondary pollutants, ammonium, nitrate, sulfate and $\mathrm{PM}_{2.5}$, under different scenarios based on GEOS-Chem simulation is shown in Figure 6.

It can be seen from Figure 6 that the high-value regions of ammonium, nitrate and sulfate in January 2015 are not consistent under the STD scenario. The high-value regions of ammonium are mainly concentrated in North China, Central China and the SCC regions. Among them, the high ammonium concentration in SCC is greater than $14 \mu \mathrm{g} / \mathrm{m}^{3}$, while in North and Central China, the high ammonium salt concentration is $6-14 \mu \mathrm{g} / \mathrm{m}^{3}$. The high concentration of nitrate is also mainly concentrated in North China, Central China and the SCC regions. The high-value region in North China has a concentration greater than $32 \mu \mathrm{g} / \mathrm{m}^{3}$, while that in the high-value region in SCC is relatively low, at $12-32 \mu \mathrm{g} / \mathrm{m}^{3}$. The concentration distribution of sulfate is mainly concentrated in the SCC region, and the concentration is usually $16-36 \mu \mathrm{g} / \mathrm{m}^{3}$. Ammonium, nitrate and sulfate are important components of $\mathrm{PM}_{2.5}$, so the high concentration of $\mathrm{PM}_{2.5}$ is a combination of the three, 
mainly concentrated in the North China, Central China and SCC regions, where the $\mathrm{PM}_{2.5}$ concentration in some regions is greater than $180 \mu \mathrm{g} / \mathrm{m}^{3}$.
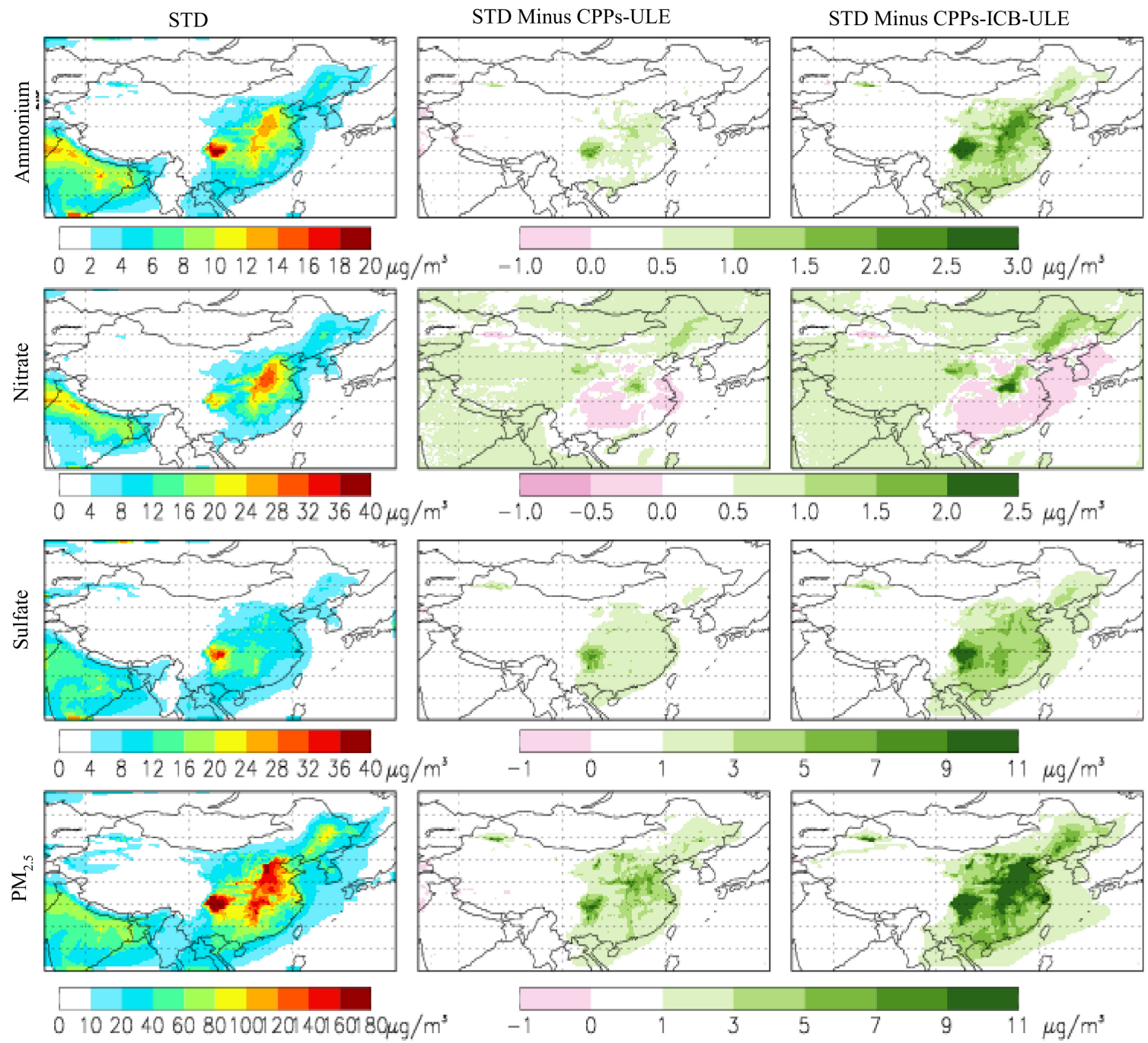

Figure 6. GEOS-Chem simulation results for nationwide distributions of ammonium, nitrate, sulfate and $\mathrm{PM}_{2.5}$. The concentrations $\left(\mu \mathrm{g} / \mathrm{m}^{3}\right)$ of ammonium, nitrate, sulfate and $\mathrm{PM}_{2.5}$ in the atmospheric surface layer under two scenarios (STD, first column, STD Minus CPPs-ULE, second column; STD Minus CPPs-ICB-ULE, third column).

Under the CPPs-ULE scenario, the reduction in the ammonium concentration is mainly concentrated in Central China, South China and the SCC region, especially in the SCC region, where it is as high as $3 \mu \mathrm{g} / \mathrm{m}^{3}$ compared with the STD scenario. The decrease in the nitrate concentration occurs mainly in the northeast, Henan and part of the western regions. Among them, the nitrate concentration in Henan decreased from $24.9 \mu \mathrm{g} / \mathrm{m}^{3}$ to $24.4 \mu \mathrm{g} / \mathrm{m}^{3}$, a decrease of $2.0 \%$, while in Urumqi, North China, SCC, the PRD and South China, the concentration of nitrate increased. The decrease in the sulfate concentration was mainly concentrated in North China, Central China, Southeastern China and the SCC regions. Among them, the concentration of sulfate in SCC decreased by as much as $11 \mu \mathrm{g} / \mathrm{m}^{3}$. The concentration of $\mathrm{PM}_{2.5}$ decreased mainly in Xinjiang Urumqi, North China, Central China, SCC and other economically developed and popular regions in Southern and Eastern China.

Under the CPPs-ICB-ULE scenario, the ICB has achieved ULE, further reducing $\mathrm{NO}_{x}$ and $\mathrm{SO}_{2}$ emissions, making the national emission reductions of ammonium, sulfate and $\mathrm{PM}_{2.5}$ more obvious. The nitrate reduction regions are also concentrated in Northeast China, Henan and part of the western regions. Among them, the decrease in Henan is 
more obvious (reduced by $4.9 \%$ ), while in Urumqi, North China, South China, SCC and $\mathrm{PRD}$, the concentration of nitrate increased more significantly.

The formation of ammonium, nitrates and sulfates in the atmosphere is all related to $\mathrm{NH}_{3}$ emissions, and there is a competition mechanism between nitrates and sulfates [17]: the ammonium ions $\left(\mathrm{NH}_{4}{ }^{+}\right)$in the atmosphere are more likely to combine with sulfate ions $\left(\mathrm{SO}_{4}{ }^{2-}\right)$ to generate ammonium sulfate $\left(\left(\mathrm{NH}_{4}\right)_{2} \mathrm{SO}_{4}\right)$. Only when $\mathrm{NH}_{3}$ is abundant will it continue to react with nitrate ions $\left(\mathrm{NO}_{3}{ }^{-}\right)$to produce ammonium nitrate $\left(\mathrm{NH}_{4} \mathrm{NO}_{3}\right)$, so the reaction between inorganic substances has the following four situations: (a) the emission of $\mathrm{NH}_{3}$ is particularly low, and there are not enough $\mathrm{NH}_{4}{ }^{+}$combined with $\mathrm{SO}_{4}{ }^{2-}$; as a result, ammonium hydrogen sulfate $\left(\mathrm{NH}_{4} \mathrm{HSO}_{4}\right)$ is formed instead of $\left(\mathrm{NH}_{4}\right)_{2} \mathrm{SO}_{4}$, and no $\mathrm{NH}_{4} \mathrm{NO}_{3}$ is formed at this time; (b) the emission of $\mathrm{NH}_{3}$ is less, and there is enough $\mathrm{NH}_{4}{ }^{+}$ combined with $\mathrm{SO}_{4}{ }^{2-}$ to form $\left(\mathrm{NH}_{4}\right)_{2} \mathrm{SO}_{4}$ and $\mathrm{NH}_{4} \mathrm{HSO}_{4}$, but no $\mathrm{NH}_{4} \mathrm{NO}_{3}$ is formed; (c) the emission of $\mathrm{NH}_{3}$ is greater, there is enough $\mathrm{NH}_{4}{ }^{+}$combined with $\mathrm{SO}_{4}{ }^{2-}$ to form $\left(\mathrm{NH}_{4}\right)_{2} \mathrm{SO}_{4}$, and the remaining $\mathrm{NH}_{4}{ }^{+}$combines with $\mathrm{NO}_{3}{ }^{-}$to form $\mathrm{NH}_{4} \mathrm{NO}_{3}$, but cannot completely consume $\mathrm{NO}_{3}{ }^{-}$; (d) the emission of $\mathrm{NH}_{3}$ is sufficient, and there is enough $\mathrm{NH}_{4}{ }^{+}$ combined with $\mathrm{SO}_{4}{ }^{2-}$ to form $\left(\mathrm{NH}_{4}\right)_{2} \mathrm{SO}_{4}$, and the remaining $\mathrm{NH}_{4}{ }^{+}$is enough to combine with the $\mathrm{NO}_{3}{ }^{-}$to form a sufficient amount of $\mathrm{NH}_{4} \mathrm{NO}_{3}$.

It can be seen that under the CPPs-ULE and CPPs-ICB-ULE scenarios, the primary pollutant $\mathrm{NO}_{\mathrm{x}}$ and $\mathrm{SO}_{2}$ emissions are significantly reduced, while the $\mathrm{NH}_{3}$ emissions in different regions remain unchanged. Based on the competition mechanism between nitrate and sulfate, the concentration of ammonium and sulfate decreases, while the concentration of nitrate decreases in some regions, but increases in other regions. The main reason is that $\mathrm{NO}_{\mathrm{x}}$ and $\mathrm{SO}_{2}$ are greatly reduced, which reduces the concentration of $\mathrm{NO}_{3}{ }^{-}$and $\mathrm{SO}_{4}{ }^{2-}$ in the atmosphere. For regions with low $\mathrm{NH}_{3}$ emissions, because $\mathrm{NH}_{3}$ emissions are lower, $\mathrm{NH}_{4}{ }^{+}$can only be combined with $\mathrm{SO}_{4}{ }^{2-}$, and it is not sufficient to consume all of it. After $\mathrm{SO}_{2}$ emission reduction, $\mathrm{NH}_{4}{ }^{+}$, originally combined with $\mathrm{SO}_{4}{ }^{2-}$, can be combined with $\mathrm{SO}_{4}{ }^{2-}$ to form $\mathrm{NH}_{4} \mathrm{HSO}_{4}$, but cannot be combined with $\mathrm{NO}_{3}{ }^{-}$to form nitrate, thus reducing the concentrations of ammonium, nitrate and sulfate.

For regions with high $\mathrm{NH}_{3}$ emissions, because $\mathrm{NH}_{3}$ emissions are high, $\mathrm{NH}_{4}{ }^{+}$will consume all the $\mathrm{SO}_{4}{ }^{2-}$, but it is not enough to combine with all $\mathrm{NO}_{3}{ }^{-}$. When $\mathrm{SO}_{2}$ is reduced, the $\mathrm{NH}_{4}{ }^{+}$originally combined with $\mathrm{SO}_{4}{ }^{2-}$ will combine with the remaining $\mathrm{NO}_{3}{ }^{-}$to form $\mathrm{NH}_{4} \mathrm{NO}_{3}$, so the concentration of nitrate will increase, and there will be surplus after the combination of $\mathrm{NH}_{4}{ }^{+}$and $\mathrm{NO}_{3}{ }^{-}$, which cannot form ammonium. Thus, the concentration of ammonium will also decrease.

Because the sulfur content of coal used in different regions, power plant boiler technology, industrial coal use, agricultural $\mathrm{NH}_{3}$ emissions, etc., are different, their individual $\mathrm{NO}_{\mathrm{x}}, \mathrm{SO}_{2}$ and $\mathrm{NH}_{3}$ emission ratios are different, which makes the implementation of ULE reduction technology challenging. The emission reduction effects in the past were different, which is ultimately reflected in the different non-linear chemical mechanisms between ammonium, nitrate and sulfate in the atmosphere of various provinces and regions, which affects the environmental benefits brought about by emission reduction policies. Therefore, in order to better reduce the concentration of $\mathrm{PM}_{2.5}$, the SCC region should focus on the emission reduction of ammonium and sulfate precursors $\mathrm{NH}_{3}$ and $\mathrm{SO}_{2}$, while, for the North and Central China areas, the focus should be on the reduction of ammonium and nitrate precursors $\mathrm{NH}_{3}$ and $\mathrm{NO}_{\mathrm{x}}$.

It can be seen from Figure 7 that, under the CPPs-ULE scenario, the emissions of primary pollutants $\mathrm{NO}_{\mathrm{x}}$ and $\mathrm{SO}_{2}$ are significantly reduced $(24.7 \%$ and $18.4 \%)$, causing the CHN concentrations of ammonium, nitrate, sulfate and $\mathrm{PM}_{2.5}$ to decrease from $3.1 \mu \mathrm{g} / \mathrm{m}^{3}$, $5.0 \mu \mathrm{g} / \mathrm{m}^{3}, 4.7 \mu \mathrm{g} / \mathrm{m}^{3}$ and $28.2 \mu \mathrm{g} / \mathrm{m}^{3}$ to $2.9 \mu \mathrm{g} / \mathrm{m}^{3}, 5.1 \mu \mathrm{g} / \mathrm{m}^{3}, 3.9 \mu \mathrm{g} / \mathrm{m}^{3}$ and $26.8 \mu \mathrm{g} / \mathrm{m}^{3}$, and decrease by $7.5 \%,-1.5 \%, 16.9 \%$ and $4.9 \%$, respectively. Under the CPPs-ICB-ULE scenario, the emissions of primary pollutants $\mathrm{NO}_{\mathrm{x}}$ and $\mathrm{SO}_{2}$ are reduced $(39.8 \%$ and $40.0 \%)$, reducing the $\mathrm{CHN}$ ammonium, nitrate, sulfate and $\mathrm{PM}_{2.5}$ concentrations to $2.6 \mu \mathrm{g} / \mathrm{m}^{3}$, $5.2 \mu \mathrm{g} / \mathrm{m}^{3}, 3.0 \mu \mathrm{g} / \mathrm{m}^{3}$ and $25.3 \mu \mathrm{g} / \mathrm{m}^{3}$, which were reduced by $16.5 \%,-2.7 \%, 35.2 \%$, and $10.1 \%$, respectively. 


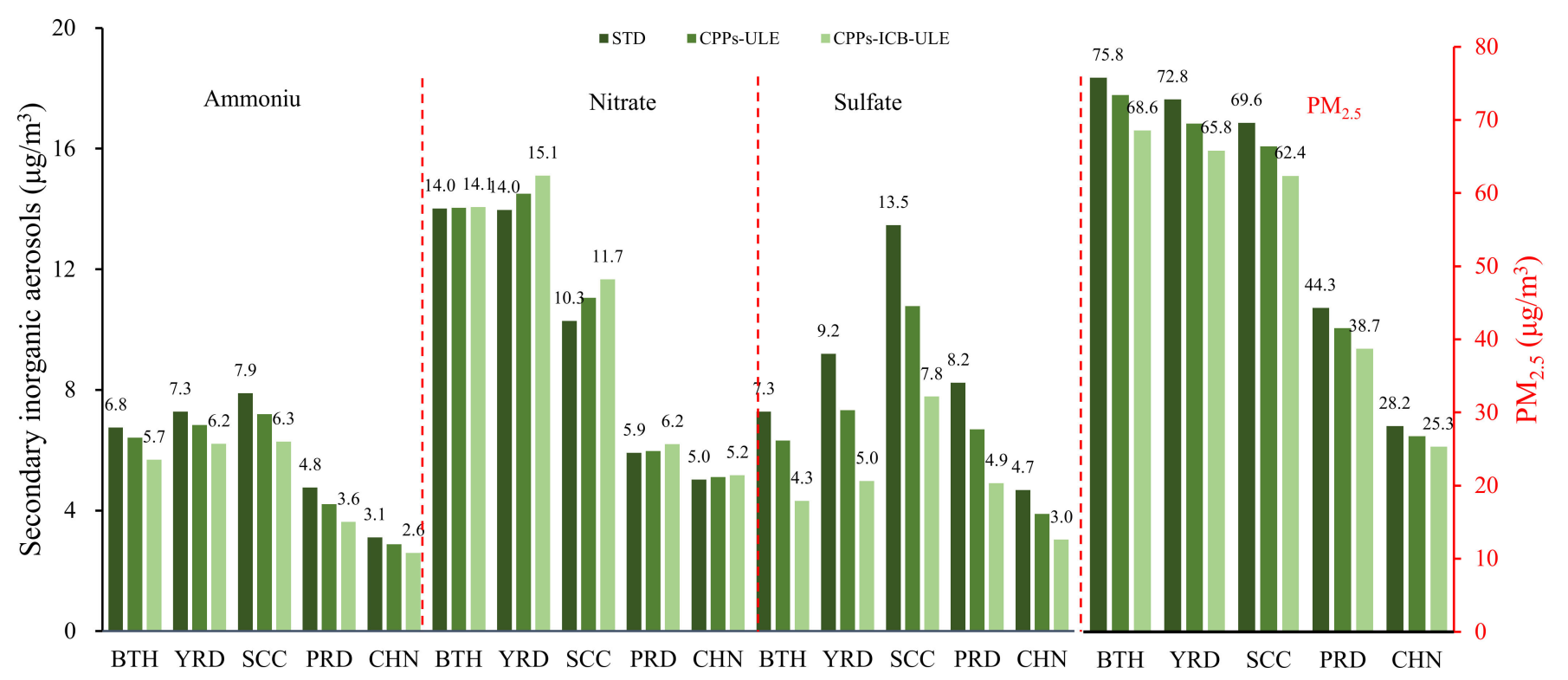

Figure 7. The reduction ratio of ammonium, nitrate, sulfate and $\mathrm{PM}_{2.5}$ in different regions under different scenarios.

In CPPs and ICB, the application of ULE reduction technology can greatly reduce the $\mathrm{NO}_{\mathrm{x}}$ and $\mathrm{SO}_{2}$ emissions, and then decrease ammonium sulfate and $\mathrm{PM}_{2.5}$ concentrations, but it increases the concentration of nitrate; therefore, the $\mathrm{CHN}$ regional $\mathrm{NH}_{3}$ emissions are too high, and only $\mathrm{NO}_{\mathrm{x}}$ and $\mathrm{SO}_{2}$ emissions are reduced; therefore, this is not the best method to reduce $\mathrm{PM}_{2.5}$ measures, and other methods should be considered according to different regional condition $\mathrm{NH}_{3}$ emissions.

Under the CPPs-ULE scenario, the BTH concentrations of ammonium, nitrate, sulfate and $\mathrm{PM}_{2.5}$ decreased from $6.8 \mu \mathrm{g} / \mathrm{m}^{3}, 14.0 \mu \mathrm{g} / \mathrm{m}^{3}, 7.3 \mu \mathrm{g} / \mathrm{m}^{3}$ and $75.8 \mu \mathrm{g} / \mathrm{m}^{3}$ to $6.4 \mu \mathrm{g} / \mathrm{m}^{3}$, $14.0 \mu \mathrm{g} / \mathrm{m}^{3}, 6.3 \mu \mathrm{g} / \mathrm{m}^{3}$ and $73.4 \mu \mathrm{g} / \mathrm{m}^{3}$, respectively, which decreased by $5.0 \%,-0.2 \%$, $13.2 \%$ and $3.1 \%$, respectively. With the realization of ULE of CPPs in the BTH region, the emissions of primary pollutants $\mathrm{NO}_{x}$ and $\mathrm{SO}_{2}$ were significantly reduced $(17.1 \%$ and $10.7 \%)$, leading to a significant decrease in the concentration of ammonium and sulfate. However, due to the competition mechanism between nitrate and sulfate, the concentration of nitrate was increased, but the proportion of the increase in nitrate concentration was relatively low $(0.2 \%)$. Under the CPPs-ICB-ULE scenario, the emissions of primary pollutants $\mathrm{NO}_{\mathrm{x}}$ and $\mathrm{SO}_{2}$ were reduced $(45.9 \%$ and $42.7 \%$ ), which could reduce the concentrations of ammonium, nitrate, sulfate and $\mathrm{PM}_{2.5}$ in the BTH region to $5.7 \mu \mathrm{g} / \mathrm{m}^{3}, 14.1 \mu \mathrm{g} / \mathrm{m}^{3}, 4.3 \mu \mathrm{g} / \mathrm{m}^{3}$ and $68.6 \mu \mathrm{g} / \mathrm{m}^{3}$, respectively, compared to the baseline scenario, which indicates reductions of $15.7 \%,-0.3 \%, 40.7 \%$ and $9.5 \%$, respectively. It can be seen that for the BTH region, there are greater $\mathrm{NH}_{3}$ emissions, but the region is not particularly affluent, because the concentration of nitrate under the different scenarios only increases by $0.2 \%$ and $0.3 \%$.

Under the CPPs-ULE scenario, the emissions of primary pollutants $\mathrm{NO}_{\mathrm{x}}$ and $\mathrm{SO}_{2}$ are significantly reduced $(25.2 \%$ and $22.0 \%)$, causing the YRD concentrations of ammonium, nitrate, sulfate and $\mathrm{PM}_{2.5}$ to decrease from $7.3 \mu \mathrm{g} / \mathrm{m}^{3}, 14.0 \mu \mathrm{g} / \mathrm{m}^{3}, 9.2 \mu \mathrm{g} / \mathrm{m}^{3}$ and $72.8 \mu \mathrm{g} / \mathrm{m}^{3}$ to $6.8 \mu \mathrm{g} / \mathrm{m}^{3}, 14.5 \mu \mathrm{g} / \mathrm{m}^{3}, 7.3 \mu \mathrm{g} / \mathrm{m}^{3}$ and $69.5 \mu \mathrm{g} / \mathrm{m}^{3}$, respectively, which are decreased by $6.1 \%,-3.9 \%, 20.3 \%$ and $4.5 \%$, respectively. Under the CPPs-ICB-ULE scenario, the emissions of primary pollutants $\mathrm{NO}_{\mathrm{x}}$ and $\mathrm{SO}_{2}$ are reduced $(40.1 \%$ and $51.0 \%)$, which can reduce the concentrations of ammonium, nitrate, sulfate and $\mathrm{PM}_{2.5}$ in the YRD region to $6.2 \mu \mathrm{g} / \mathrm{m}^{3}, 15.1 \mu \mathrm{g} / \mathrm{m}^{3}, 5.0 \mu \mathrm{g} / \mathrm{m}^{3}$ and $65.8 \mu \mathrm{g} / \mathrm{m}^{3}$, respectively, compared to the baseline scenario, with reductions of $14.7 \%,-8.2 \%, 45.9 \%$ and $9.6 \%$, respectively. It can be seen that, compared with the BTH region, YRD is richer in $\mathrm{NH}_{3}$ emissions. After the ULE of CPPs is completed, the nitrate concentration is increased by $3.9 \%$. With the completion of the ULE of ICB, it has further reduced the emissions of $\mathrm{NO}_{\mathrm{X}}$ and $\mathrm{SO}_{2}$ and has increased 
the concentration of nitrate to $8.2 \%$. The YRD region pays more attention to $\mathrm{NH}_{3}$ emission reduction control than the $\mathrm{BTH}$ region.

Under the CPPs-ULE scenario, the emissions of primary pollutants $\mathrm{NO}_{\mathrm{x}}$ and $\mathrm{SO}_{2}$ are significantly reduced $(15.2 \%$ and $18.6 \%)$, causing the SCC concentrations of ammonium, nitrate, sulfate and $\mathrm{PM}_{2.5}$ to decrease from $7.9 \mu \mathrm{g} / \mathrm{m}^{3}, 10.3 \mu \mathrm{g} / \mathrm{m}^{3}, 13.5 \mu \mathrm{g} / \mathrm{m}^{3}$ and $69.6 \mu \mathrm{g} / \mathrm{m}^{3}$ to $7.2 \mu \mathrm{g} / \mathrm{m}^{3}, 11.1 \mu \mathrm{g} / \mathrm{m}^{3}, 10.8 \mu \mathrm{g} / \mathrm{m}^{3}$ and $66.4 \mu \mathrm{g} / \mathrm{m}^{3}$, respectively, amounting to reductions of $8.8 \%,-7.5 \%, 20.0 \%$ and $4.6 \%$, respectively. Under the CPPs-ICB-ULE scenario, the emissions of primary pollutants $\mathrm{NO}_{\mathrm{x}}$ and $\mathrm{SO}_{2}$ are reduced $(26.1 \%$ and $45.9 \%)$, which can reduce the concentrations of ammonium, nitrate, sulfate and $\mathrm{PM}_{2.5}$ in the SCC region to $6.3 \mu \mathrm{g} / \mathrm{m}^{3}, 11.7 \mu \mathrm{g} / \mathrm{m}^{3}, 7.8 \mu \mathrm{g} / \mathrm{m}^{3}$ and $62.4 \mu \mathrm{g} / \mathrm{m}^{3}$, respectively, compared to the baseline scenario, with reductions of $20.3 \%,-13.4 \%, 42.2 \%$ and $10.4 \%$, respectively. It can be seen that, compared with the BTH and YRD regions, SCC has the most abundant $\mathrm{NH}_{3}$ emissions. After the ULE of CPPs is completed, the nitrate concentration is increased by $7.5 \%$. With the completion of the ULE of ICB, it has further reduced the emissions of $\mathrm{NO}_{X}$ and $\mathrm{SO}_{2}$ and has increased the concentration of nitrate to $13.4 \%$. The SCC region is in urgent need of $\mathrm{NH}_{3}$ emission control compared with the PRD region.

Under the CPPs-ULE scenario, the emissions of primary pollutants $\mathrm{NO}_{\mathrm{x}}$ and $\mathrm{SO}_{2}$ are significantly reduced $(23.0 \%$ and $23.0 \%)$, causing the PRD concentrations of ammonium, nitrate, sulfate and $\mathrm{PM}_{2.5}$ to decrease from $4.8 \mu \mathrm{g} / \mathrm{m}^{3}, 5.9 \mu \mathrm{g} / \mathrm{m}^{3}, 8.2 \mu \mathrm{g} / \mathrm{m}^{3}$ and $44.3 \mu \mathrm{g} / \mathrm{m}^{3}$ to $4.2 \mu \mathrm{g} / \mathrm{m}^{3}, 6.0 \mu \mathrm{g} / \mathrm{m}^{3}, 6.7 \mu \mathrm{g} / \mathrm{m}^{3}$ and $41.6 \mu \mathrm{g} / \mathrm{m}^{3}$, respectively, amounting to reductions of $11.4 \%,-1.0 \%, 18.8 \%$ and $6.2 \%$, respectively. Under the CPPs-ICB-ULE scenario, the emissions of primary pollutants $\mathrm{NO}_{x}$ and $\mathrm{SO}_{2}$ are reduced (33.1\% and $49.4 \%$ ), which can reduce the concentrations of ammonium, nitrate, sulfate and $\mathrm{PM}_{2.5}$ in the PRD region to $3.6 \mu \mathrm{g} / \mathrm{m}^{3}, 6.2 \mu \mathrm{g} / \mathrm{m}^{3}, 4.9 \mu \mathrm{g} / \mathrm{m}^{3}$ and $38.7 \mu \mathrm{g} / \mathrm{m}^{3}$, respectively, compared to the baseline scenario, with reductions of $23.9 \%,-4.9 \%, 40.5 \%$ and $12.7 \%$, respectively.

It can be seen that the PRD area has more $\mathrm{NH}_{3}$ emissions than the BTH, but it is not richer than YRD and SCC. Therefore, after the ULE of CPPs is completed, the nitrate concentration is increased by $1.0 \%$. With the completion of the ULE of ICB, it has further reduced the emissions of $\mathrm{NO}_{\mathrm{X}}$ and $\mathrm{SO}_{2}$ and has increased the concentration of nitrate to $4.9 \%$.

\subsection{Environmental Benefits of $\mathrm{NH}_{3}$ Emission Reduction}

The spatial distribution of the concentrations of secondary pollutants, ammonium, nitrate, sulfate and $\mathrm{PM}_{2.5}$, under the $\mathrm{NH}_{3}$ emission reduction control scenario based on GEOS-Chem simulation is shown in Figure 8.

As can be seen from Figure 8, under the CPPs-ULE-NH $\mathrm{N}_{3}-30 \%$ scenario, the ULE of CPPs with $\mathrm{NH}_{3}$ emission reduced by $30 \%$ at the same time can cause the national ammonium, nitrate and $\mathrm{PM}_{2.5}$ concentrations to significantly decrease, and the concentration of sulfate has no obvious change relative to the STD scenario. The main reason for this is the reduction of $\mathrm{NH}_{3}$ in the atmosphere, which reduces the concentration of $\mathrm{NH}_{4}{ }^{+}$. Because of the non-linear mechanism of ammonium, nitrate and sulfate, $\mathrm{NH}_{4}{ }^{+}$is preferentially combined with $\mathrm{SO}_{4}{ }^{2-}$ to form sulfate, and there is not enough $\mathrm{NH}_{4}{ }^{+}$to combine with $\mathrm{NO}_{3}{ }^{-}$to produce nitrate, so the concentration of ammonium and nitrate is significantly reduced. As the $\mathrm{NH}_{3}$ emission reduction reaches $50 \%$, the concentrations of ammonium, nitrate and $\mathrm{PM}_{2.5}$ can still be further reduced, but this cannot cause a significant change in the concentration of sulfate. This shows that when $\mathrm{NH}_{3}$ is reduced by $50 \%$, the combination of $\mathrm{NH}_{4}{ }^{+}$and $\mathrm{SO}_{4}{ }^{2-}$ is not affected. In order to better reduce $\mathrm{PM}_{2.5}$, the emission of one or more pollutants can be further reduced according to the cost of the emission reduction of $\mathrm{NO}_{x}, \mathrm{SO}_{2}$ and $\mathrm{NH}_{3}$. On the basis of CPPs-ICB-ULE, the $\mathrm{NH}_{3}$ emission reduction was 30\% and $50 \%$, respectively, making the changes of ammonium salt, nitrate, sulfate and $\mathrm{PM}_{2.5}$ in the atmosphere consistent with the changes in the $\mathrm{NH}_{3}$ emission reduction on the basis of CPPs-ULE. $\mathrm{NH}_{3}$ emission reduction can significantly reduce the concentration of nitrate while reducing the ammonium and sulfate in $\mathrm{PM}_{2.5}$. 

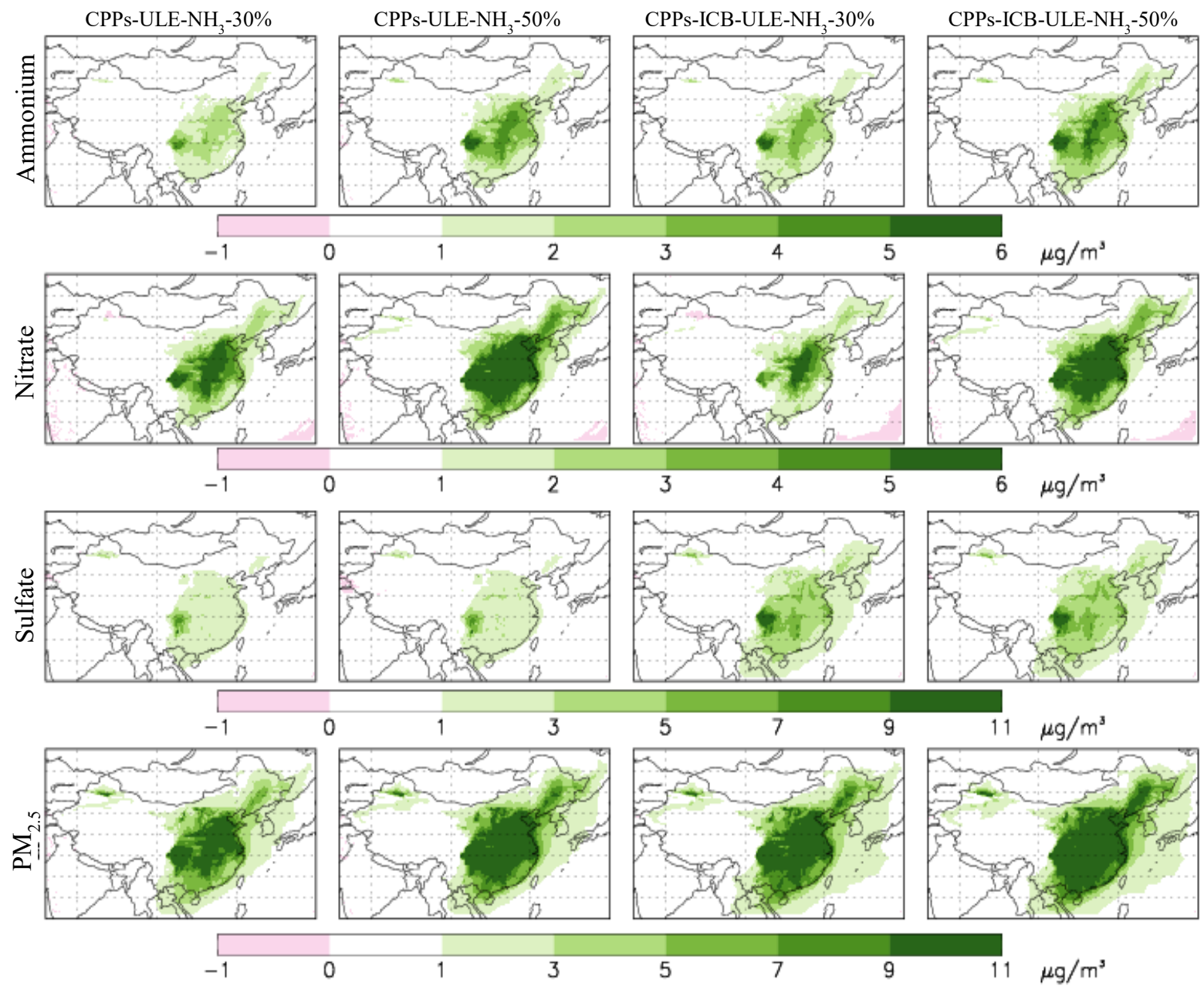

Figure 8. GEOS-Chem simulation results for nationwide distributions of ammonium, nitrate, sulfate and $\mathrm{PM}_{2.5}$. The concentrations $\left(\mu \mathrm{g} / \mathrm{m}^{3}\right)$ of ammonium, nitrate, sulfate and $\mathrm{PM}_{2.5}$ in the atmospheric surface layer relative to STD scenarios (STD Minus CPPs-ULE-NH $-30 \%$, first column, STD Minus CPPs-ULE-NH $\mathrm{N}_{3}-50 \%$, second column; STD Minus CPPs-ICBULE-NH $-30 \%$, third column; STD Minus CPPs-ICB-ULE-NH $3-50 \%$, fourth column).

As can be seen from Figure 9, compared with the STD scenario, $\mathrm{NH}_{3}$ was reduced by $30 \%$ on the basis of CPPs-ULE, and the concentrations of CHN ammonium, nitrate, sulfate and $\mathrm{PM}_{2.5}$ decreased from $3.1 \mu \mathrm{g} / \mathrm{m}^{3}, 5.0 \mu \mathrm{g} / \mathrm{m}^{3}, 4.7 \mu \mathrm{g} / \mathrm{m}^{3}$ and $28.2 \mu \mathrm{g} / \mathrm{m}^{3}$ to $2.4 \mu \mathrm{g} / \mathrm{m}^{3}$, $3.7 \mu \mathrm{g} / \mathrm{m}^{3}, 3.9 \mu \mathrm{g} / \mathrm{m}^{3}$ and $24.9 \mu \mathrm{g} / \mathrm{m}^{3}$, amounting to reductions of $21.8 \%, 26.0 \%, 17.3 \%$ and $11.5 \%$, respectively. With the reduction of $\mathrm{NH}_{3}$ by $50 \%$, the concentration of $\mathrm{CHN}$ ammonium, nitrate, sulfate and $\mathrm{PM}_{2.5}$ decreased to $2.1 \mu \mathrm{g} / \mathrm{m}^{3}, 2.7 \mu \mathrm{g} / \mathrm{m}^{3}, 3.8 \mu \mathrm{g} / \mathrm{m}^{3}$ and $23.5 \mathrm{\mu g} / \mathrm{m}^{3}$, with reductions of $33.4 \%, 46.8 \%, 17.8 \%$ and $16.5 \%$, respectively. Compared with the STD scenario, $\mathrm{NH}_{3}$ was reduced by $30 \%$ on the basis of CPPs-ICB-ULE, and the concentrations of CHN ammonium, nitrate, sulfate and $\mathrm{PM}_{2.5}$ were reduced to $2.2 \mu \mathrm{g} / \mathrm{m}^{3}$, $4.0 \mu \mathrm{g} / \mathrm{m}^{3}, 3.0 \mu \mathrm{g} / \mathrm{m}^{3}$ and $23.8 \mu \mathrm{g} / \mathrm{m}^{3}$, amounting to $28.3 \%, 20.7 \%, 35.4 \%$ and $15.6 \%$, respectively. With the reduction of $\mathrm{NH}_{3}$ by $50 \%$, the concentrations of $\mathrm{CHN}$ ammonium, nitrate, sulfate and $\mathrm{PM}_{2.5}$ decreased to $1.9 \mu \mathrm{g} / \mathrm{m}^{3}, 3.0 \mu \mathrm{g} / \mathrm{m}^{3}, 3.0 \mu \mathrm{g} / \mathrm{m}^{3}$ and $22.4 \mu \mathrm{g} / \mathrm{m}^{3}$, amounting to $38.4 \%, 40.4 \%, 35.6 \%$ and $20.3 \%$, respectively.

Compared with the STD scenario, $\mathrm{NH}_{3}$ was reduced by $30 \%$ on the basis of CPPs-ULE, and the concentrations of BTH ammonium, nitrate, sulfate and $\mathrm{PM}_{2.5}$ decreased from $6.8 \mu \mathrm{g} / \mathrm{m}^{3}, 14.0 \mu \mathrm{g} / \mathrm{m}^{3}, 7.3 \mu \mathrm{g} / \mathrm{m}^{3}$ and $75.8 \mu \mathrm{g} / \mathrm{m}^{3}$ to $5.4 \mu \mathrm{g} / \mathrm{m}^{3}, 10.8 \mu \mathrm{g} / \mathrm{m}^{3}, 6.2 \mu \mathrm{g} / \mathrm{m}^{3}$ and $69.0 \mu \mathrm{g} / \mathrm{m}^{3}$, amounting to $20.0 \%, 23.1 \%, 14.8 \%$ and $8.9 \%$, respectively. With the reduction of $\mathrm{NH}_{3}$ by $50 \%$, the concentration of $\mathrm{BTH}$ ammonium, nitrate, sulfate and $\mathrm{PM}_{2.5}$ decreased to $4.5 \mu \mathrm{g} / \mathrm{m}^{3}, 8.0 \mu \mathrm{g} / \mathrm{m}^{3}, 6.1 \mu \mathrm{g} / \mathrm{m}^{3}$ and $65.2 \mu \mathrm{g} / \mathrm{m}^{3}$, amounting to $33.0 \%, 42.8 \%$, $16.5 \%$ and $13.9 \%$, respectively. Compared with the STD scenario, $\mathrm{NH}_{3}$ was reduced by 
$30 \%$ on the basis of CPPs-ICB-ULE, and the concentrations of BTH ammonium, nitrate, sulfate and $\mathrm{PM}_{2.5}$ were reduced to $4.9 \mu \mathrm{g} / \mathrm{m}^{3}, 11.4 \mu \mathrm{g} / \mathrm{m}^{3}, 4.3 \mu \mathrm{g} / \mathrm{m}^{3}$ and $65.1 \mu \mathrm{g} / \mathrm{m}^{3}$, which were reduced by $18.4 \%, 20.7 \%, 41.5 \%$ and $14.1 \%$, respectively. With the reduction of $\mathrm{NH}_{3}$ by $50 \%$, the concentration of $\mathrm{BTH}$ ammonium, nitrate, sulfate and $\mathrm{PM}_{2.5}$ decreased to $4.1 \mu \mathrm{g} / \mathrm{m}^{3}, 9.0 \mu \mathrm{g} / \mathrm{m}^{3}, 4.2 \mu \mathrm{g} / \mathrm{m}^{3}$ and $61.8 \mu \mathrm{g} / \mathrm{m}^{3}$, which were reduced by $38.6 \%, 36.0 \%$, $42.4 \%$ and $18.4 \%$, respectively.

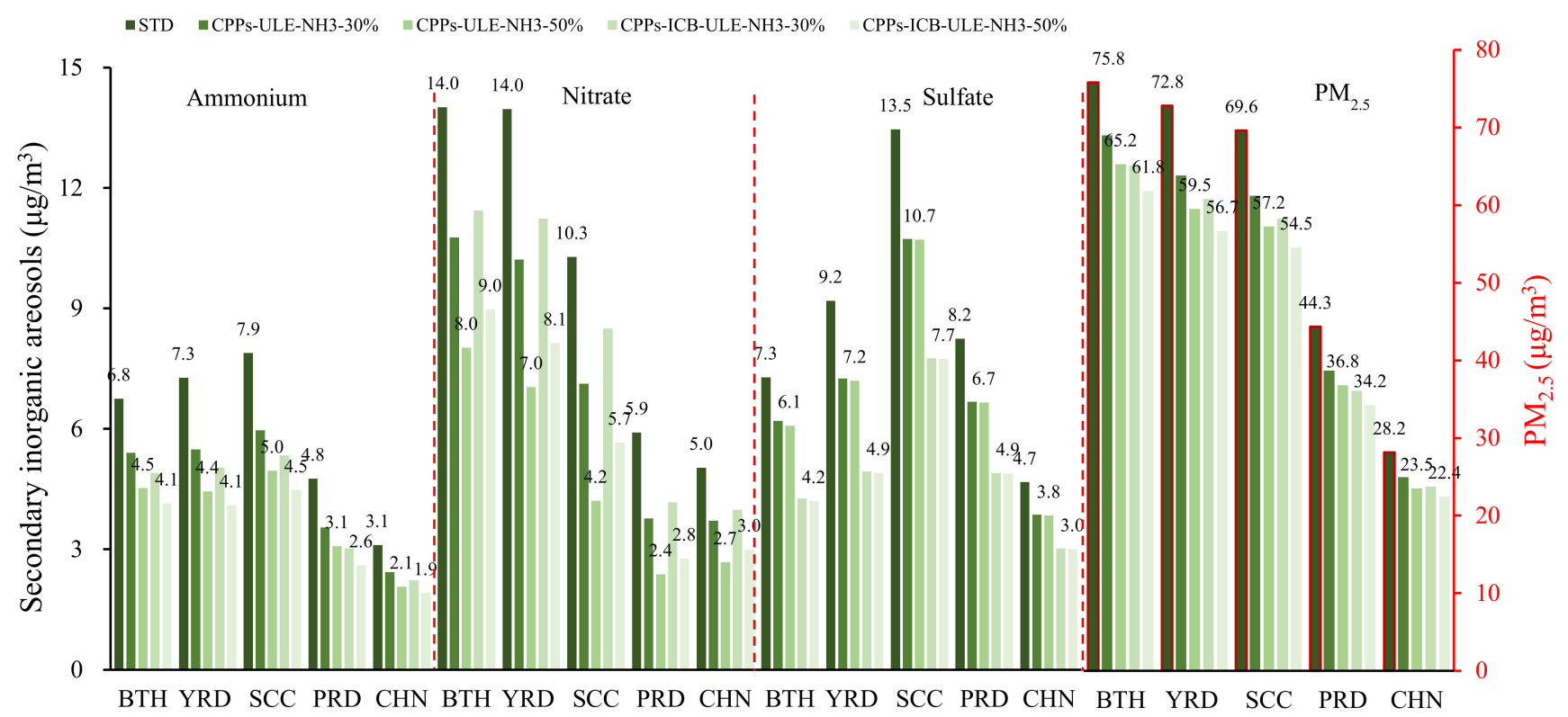

Figure 9. The reduction ratio of ammonium, nitrate, sulfate and $\mathrm{PM}_{2.5}$ in different regions under different scenarios.

Compared with the STD scenario, $\mathrm{NH}_{3}$ was reduced by $30 \%$ on the basis of CPPs-ULE, and the concentrations of YRD ammonium, nitrate, sulfate and $\mathrm{PM}_{2.5}$ decreased from $7.3 \mu \mathrm{g} / \mathrm{m}^{3}, 14.0 \mu \mathrm{g} / \mathrm{m}^{3}, 9.2 \mu \mathrm{g} / \mathrm{m}^{3}$ and $72.8 \mu \mathrm{g} / \mathrm{m}^{3}$ to $5.5 \mu \mathrm{g} / \mathrm{m}^{3}, 10.2 \mu \mathrm{g} / \mathrm{m}^{3}, 7.3 \mu \mathrm{g} / \mathrm{m}^{3}$ and $63.8 \mu \mathrm{g} / \mathrm{m}^{3}$, which were reduced by $24.6 \%, 26.8 \%, 21.0 \%$ and $12.3 \%$, respectively. With the reduction of $\mathrm{NH}_{3}$ by $50 \%$, the concentration of YRD ammonium, nitrate, sulfate and $\mathrm{PM}_{2.5}$ decreased to $4.4 \mu \mathrm{g} / \mathrm{m}^{3}, 7.0 \mu \mathrm{g} / \mathrm{m}^{3}, 7.2 \mu \mathrm{g} / \mathrm{m}^{3}$ and $59.5 \mu \mathrm{g} / \mathrm{m}^{3}$, which were reduced by $39.0 \%, 49.5 \%, 21.7 \%$ and $18.2 \%$, respectively. Compared with the STD scenario, $\mathrm{NH}_{3}$ was reduced by $30 \%$ on the basis of CPPs-ICB-ULE, and the concentrations of YRD ammonium, nitrate, sulfate and $\mathrm{PM}_{2.5}$ were reduced to $5.0 \mu \mathrm{g} / \mathrm{m}^{3}, 11.2 \mu \mathrm{g} / \mathrm{m}^{3}, 4.9 \mu \mathrm{g} / \mathrm{m}^{3}$ and $60.8 \mu \mathrm{g} / \mathrm{m}^{3}$, amounting to $30.6 \%, 19.5 \%, 46.3 \%$ and $16.5 \%$, respectively. With the reduction of $\mathrm{NH}_{3}$ by $50 \%$, the concentrations of $\mathrm{CHN}$ ammonium, nitrate, sulfate and $\mathrm{PM}_{2.5}$ decreased to $4.1 \mu \mathrm{g} / \mathrm{m}^{3}, 8.1 \mu \mathrm{g} / \mathrm{m}^{3}, 4.9 \mu \mathrm{g} / \mathrm{m}^{3}$ and $56.7 \mu \mathrm{g} / \mathrm{m}^{3}$, which were reduced by $43.7 \%, 41.7 \%, 46.7 \%$ and $22.1 \%$, respectively.

Compared with the STD scenario, $\mathrm{NH}_{3}$ was reduced by $30 \%$ on the basis of CPPs-ULE, and the concentrations of SCC ammonium, nitrate, sulfate and $\mathrm{PM}_{2.5}$ decreased from $7.9 \mu \mathrm{g} / \mathrm{m}^{3}, 10.3 \mu \mathrm{g} / \mathrm{m}^{3}, 13.5 \mu \mathrm{g} / \mathrm{m}^{3}$ and $69.6 \mu \mathrm{g} / \mathrm{m}^{3}$ to $6.0 \mu \mathrm{g} / \mathrm{m}^{3}, 7.1 \mu \mathrm{g} / \mathrm{m}^{3}, 10.7 \mu \mathrm{g} / \mathrm{m}^{3}$ and $61.2 \mu \mathrm{g} / \mathrm{m}^{3}$, which were reduced by $24.4 \%, 30.7 \%, 20.3 \%$ and $12.1 \%$, respectively. With the reduction of $\mathrm{NH}_{3}$ by $50 \%$, the concentrations of SCC ammonium, nitrate, sulfate and $\mathrm{PM}_{2.5}$ decreased to $5.0 \mu \mathrm{g} / \mathrm{m}^{3}, 4.2 \mu \mathrm{g} / \mathrm{m}^{3}, 10.7 \mu \mathrm{g} / \mathrm{m}^{3}$ and $57.2 \mu \mathrm{g} / \mathrm{m}^{3}$, which were reduced by $37.2 \%, 59.1 \%, 20.4 \%$ and $17.8 \%$, respectively. Compared with the STD scenario, $\mathrm{NH}_{3}$ was reduced by $30 \%$ on the basis of CPPs-ICB-ULE, and the concentrations of SCC ammonium, nitrate, sulfate and $\mathrm{PM}_{2.5}$ were reduced to $5.3 \mu \mathrm{g} / \mathrm{m}^{3}, 8.5 \mu \mathrm{g} / \mathrm{m}^{3}, 7.8 \mu \mathrm{g} / \mathrm{m}^{3}$ and $58.2 \mu \mathrm{g} / \mathrm{m}^{3}$, which were reduced by $32.4 \%, 17.4 \%, 42.4 \%$ and $16.3 \%$, respectively. With the reduction of $\mathrm{NH}_{3}$ by $50 \%$, the concentrations of SCC ammonium, nitrate, sulfate and $\mathrm{PM}_{2.5}$ decreased to $4.5 \mu \mathrm{g} / \mathrm{m}^{3}, 5.7 \mu \mathrm{g} / \mathrm{m}^{3}, 7.7 \mu \mathrm{g} / \mathrm{m}^{3}$ and $54.5 \mu \mathrm{g} / \mathrm{m}^{3}$, which were reduced by $43.3 \%, 45.0 \%, 42.5 \%$ and $21.7 \%$, respectively. 
Compared with the STD scenario, $\mathrm{NH}_{3}$ was reduced by $30 \%$ on the basis of CPPs-ULE, and the concentrations of PRD ammonium, nitrate, sulfate and $\mathrm{PM}_{2.5}$ decreased from $4.8 \mu \mathrm{g} / \mathrm{m}^{3}, 5.9 \mu \mathrm{g} / \mathrm{m}^{3}, 8.2 \mu \mathrm{g} / \mathrm{m}^{3}$ and $44.3 \mu \mathrm{g} / \mathrm{m}^{3}$ to $3.5 \mu \mathrm{g} / \mathrm{m}^{3}, 3.8 \mu \mathrm{g} / \mathrm{m}^{3}, 6.7 \mu \mathrm{g} / \mathrm{m}^{3}$ and $38.7 \mu \mathrm{g} / \mathrm{m}^{3}$, which were reduced by $25.5 \%, 36.2 \%, 19.0 \%$ and $12.7 \%$, respectively. With the reduction of $\mathrm{NH}_{3}$ by $50 \%$, the concentrations of PRD ammonium, nitrate, sulfate and $\mathrm{PM}_{2.5}$ decreased to $3.1 \mu \mathrm{g} / \mathrm{m}^{3}, 2.4 \mu \mathrm{g} / \mathrm{m}^{3}, 6.7 \mu \mathrm{g} / \mathrm{m}^{3}$ and $36.8 \mu \mathrm{g} / \mathrm{m}^{3}$, which were reduced by $35.3 \%, 59.7 \%, 19.2 \%$ and $17.0 \%$, respectively. Compared with the STD scenario, $\mathrm{NH}_{3}$ was reduced by $30 \%$ on the basis of CPPs-ICB-ULE, and the concentrations of PRD ammonium, nitrate, sulfate and $\mathrm{PM}_{2.5}$ were reduced to $3.0 \mu \mathrm{g} / \mathrm{m}^{3}, 4.2 \mu \mathrm{g} / \mathrm{m}^{3}, 4.9 \mu \mathrm{g} / \mathrm{m}^{3}$ and $36.1 \mu \mathrm{g} / \mathrm{m}^{3}$, which were reduced by $36.5 \%, 29.5 \%, 40.6 \%$ and $18.6 \%$, respectively. With the reduction of $\mathrm{NH}_{3}$ by $50 \%$, the concentrations of $\mathrm{CHN}$ ammonium, nitrate, sulfate and $\mathrm{PM}_{2.5}$ decreased to $2.6 \mu \mathrm{g} / \mathrm{m}^{3}, 2.8 \mu \mathrm{g} / \mathrm{m}^{3}, 4.9 \mu \mathrm{g} / \mathrm{m}^{3}$ and $34.2 \mu \mathrm{g} / \mathrm{m}^{3}$, amounting to reductions of $45.3 \%, 53.1 \%, 40.6 \%$ and $22.7 \%$, respectively.

\subsection{Discussion}

Although the CPPs have achieved the ULE transformation target, the $\mathrm{PM}_{2.5}$ concentration across the country has decreased by $4.8 \%\left(1.4 \mu \mathrm{g} / \mathrm{m}^{3}\right)$ compared with January 2015, and haze pollution is still very serious. In addition, ammonium, nitrate and sulfate are important components of $\mathrm{PM}_{2.5}$. Due to the complex non-linear chemical competition mechanism among them, the average concentration of nitrate in $\mathrm{CHN}$ increases by $1.5 \%$ $\left(0.1 \mu \mathrm{g} / \mathrm{m}^{3}\right)$ under the condition of a large reduction in $\mathrm{NO}_{\mathrm{x}}$ and $\mathrm{SO}_{2}$ emissions, which reduces the environmental benefits of power plant emission reduction. If the ULE technology is applied to the ICB to further reduce $\mathrm{NO}_{\mathrm{x}}$ and $\mathrm{SO}_{2}$, although the $\mathrm{PM}_{2.5}$ concentration can be reduced by $10.1 \%\left(2.9 \mu \mathrm{g} / \mathrm{m}^{3}\right)$, the concentration of nitrate will increase by $2.7 \%$ $\left(0.2 \mu \mathrm{g} / \mathrm{m}^{3}\right)$. It can be seen that reducing the emission of $\mathrm{NO}_{\mathrm{x}}$ and $\mathrm{SO}_{2}$ does not reduce the concentration of $\mathrm{PM}_{2.5}$ well, and the haze pollution is still very serious.

On the basis of CPPs-ULE, $\mathrm{NH}_{3}$ emissions are reduced by $30 \%$, which can reduce the national $\mathrm{PM}_{2.5}$ concentration by $11.5 \%$ (reduced by $3.3 \mu \mathrm{g} / \mathrm{m}^{3}$ ), by significantly reducing the ammonium (reduced by $21.8 \%$ ) and nitrate (reduced by $26.0 \%$ ) concentrations, to achieve a better $\mathrm{PM}_{2.5}$ reduction effect than ULE of ICB. If the $\mathrm{NH}_{3}$ emission reduction reaches $50 \%$, the concentrations of ammonium (reduced by $33.4 \%$ ), nitrate (reduced by $46.8 \%$ ) and sulfate can be further reduced, and the $\mathrm{PM}_{2.5}$ concentration can be reduced by $16.5 \%\left(4.7 \mu \mathrm{g} / \mathrm{m}^{3}\right)$. Similarly, on the basis of CPPs-ICB-ULE, $\mathrm{NH}_{3}$ emissions are reduced by $30 \%$ and $50 \%$, which can reduce the national $\mathrm{PM}_{2.5}$ concentration by $15.6 \%\left(4.4 \mu \mathrm{g} / \mathrm{m}^{3}\right)$ and $20.3 \%\left(5.8 \mu \mathrm{g} / \mathrm{m}^{3}\right)$, by significantly reducing the ammonium and nitrate concentrations.

In conclusion, $\mathrm{NO}_{\mathrm{x}}, \mathrm{SO}_{2}$ and $\mathrm{NH}_{3}$ emission reduction have the same $\mathrm{PM}_{2.5}$ reduction effect. ULE of CPPs and ICB reduces the $\mathrm{PM}_{2.5}$ concentration by reducing $\mathrm{NO}_{\mathrm{x}}$ and $\mathrm{SO}_{2}$, and then reducing the concentrations of ammonium and sulfate, while $\mathrm{NH}_{3}$ emission reduction mainly reduces the $\mathrm{PM}_{2.5}$ concentration by reducing the concentration of ammonium and nitrate. In order to better reduce the concentration of $\mathrm{PM}_{2.5}$, the emission reduction control measures of $\mathrm{NO}_{\mathrm{x}}, \mathrm{SO}_{2}$ and $\mathrm{NH}_{3}$ should be formulated according to the specific conditions of different regions.

As can be seen from Figure 10, for the BTH region in the CPPs-ULE scenario, as with the $\mathrm{NO}_{\mathrm{x}}$ and $\mathrm{SO}_{2}$ emission reduction, the concentrations of ammonium and sulfate were reduced by $5.0 \%$ and $13.2 \%$ respectively, while the concentration of nitrate increased by $0.2 \%$, and the concentration of $\mathrm{PM}_{2.5}$ was reduced by $3.1 \%\left(2.5 \mu \mathrm{g} / \mathrm{m}^{3}\right)$. Under the CPPs-ICB-ULE scenario, with the further decrease in $\mathrm{NO}_{x}$ and $\mathrm{SO}_{2}$, the concentrations of ammonium and sulfate decreased by $15.7 \%$ and $40.7 \%$, respectively, while the concentration of nitrate increased by $0.3 \%$, and the concentration of $\mathrm{PM}_{2.5}$ decreased by $9.5 \%$ $\left(7.2 \mu \mathrm{g} / \mathrm{m}^{3}\right)$. Therefore, relative to the CPPs-ULE scenario, reducing the emissions of $\mathrm{NH}_{3}$ can significantly reduce the concentrations of nitrate and ammonium, and reduces the sulfate concentration by $1.6 \%$. This indicates that the atmospheric $\mathrm{NH}_{3}$ emission in the $\mathrm{BTH}$ region is insufficient, and $\mathrm{NH}_{4}{ }^{+}$is insufficient to combine with all $\mathrm{SO}_{4}{ }^{2-}$. When the $\mathrm{NH}_{3}$ emission is reduced to $50 \%$, the concentrations of ammonium, nitrate and sulfate 
can be reduced by $33.0 \%, 42.8 \%$ and $16.5 \%$, respectively, and the concentration of $\mathrm{PM}_{2.5}$ can be reduced by $13.9 \%\left(10.6 \mu \mathrm{g} / \mathrm{m}^{3}\right)$. On the basis of CPPs-ICB-ULE, the emission of $\mathrm{NH}_{3}$ was reduced by $30 \%$, the concentrations of ammonium, nitrate and sulfate were reduced by $27.5 \%, 18.4 \%$ and $41.5 \%$, respectively, and the concentration of $\mathrm{PM}_{2.5}$ was decreased by $14.1 \%\left(10.7 \mu \mathrm{g} / \mathrm{m}^{3}\right)$. With the reduction of $\mathrm{NH}_{3}$ to $50 \%$, the concentrations of ammonium, nitrate and sulfate were decreased by $38.6 \%, 36.0 \%$ and $42.5 \%$, respectively, and the concentration of $\mathrm{PM}_{2.5}$ was decreased by $18.4 \%\left(14.0 \mu \mathrm{g} / \mathrm{m}^{3}\right)$. In conclusion, after the completion of ULE of CPPs in the BTH region, the synergistic effect of $\mathrm{NH}_{3}$ emission reduction should be comprehensively considered while promoting ULE technology in the field of ICB.

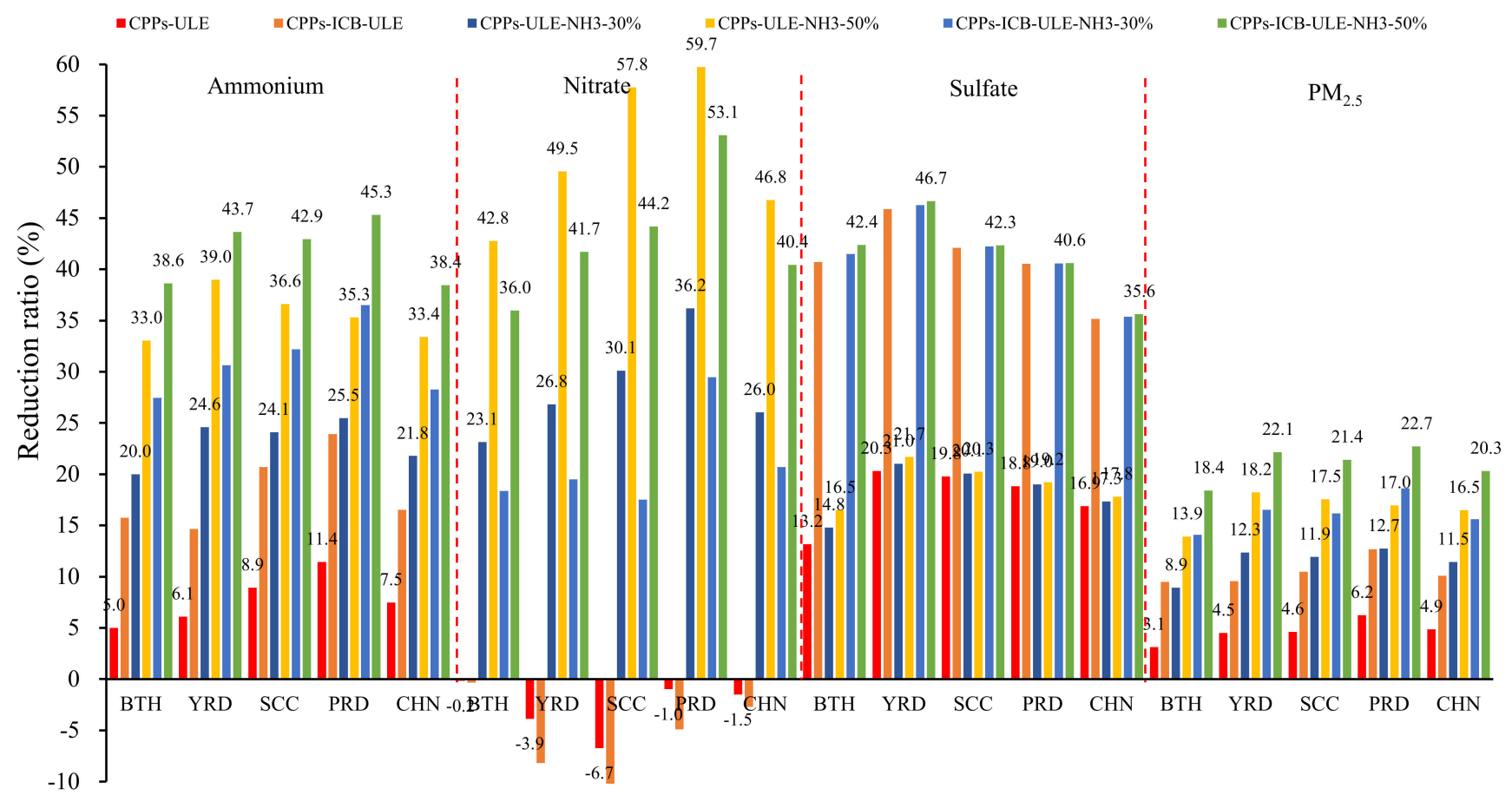

Figure 10. The average concentration reduction ratios of secondary pollutants ammonium, nitrate, sulfate and $\mathrm{PM}_{2.5}$ of China simulated by GEOS-Chem under different scenarios relative to STD scenario.

For the YRD region in the CPPs-ULE scenario, as with the $\mathrm{NO}_{\mathrm{x}}$ and $\mathrm{SO}_{2}$ emission reduction, the concentrations of ammonium and sulfate were reduced by $6.1 \%$ and $20.3 \%$, respectively, while the concentration of nitrate increased by $3.9 \%\left(0.5 \mu \mathrm{g} / \mathrm{m}^{3}\right)$, and the concentration of $\mathrm{PM}_{2.5}$ was reduced by $4.5 \%\left(3.3 \mu \mathrm{g} / \mathrm{m}^{3}\right)$. Under the CPPs-ICB-ULE scenario, with the further decrease in $\mathrm{NO}_{\mathrm{x}}$ and $\mathrm{SO}_{2}$, the concentration of ammonium and sulfate decreased by $14.7 \%$ and $45.9 \%$, respectively, while the concentration of nitrate increased by $8.2 \%\left(1.1 \mu \mathrm{g} / \mathrm{m}^{3}\right)$, and the concentration of $\mathrm{PM}_{2.5}$ decreased by $9.6 \%\left(7.0 \mu \mathrm{g} / \mathrm{m}^{3}\right)$. Therefore, relative to the CPPs-ULE scenario, an emission reduction of $\mathrm{NH}_{3}$ by $30 \%$ can significantly reduce the concentrations of nitrate and ammonium, and also reduces the sulfate concentration by $0.7 \%$. This indicates that the atmospheric $\mathrm{NH}_{3}$ emission in the YRD region is insufficient, and $\mathrm{NH}_{4}{ }^{+}$is insufficient to combine with all $\mathrm{SO}_{4}{ }^{2-}$. When the $\mathrm{NH}_{3}$ emission is reduced to $50 \%$, the concentrations of ammonium, nitrate and sulfate can be reduced by $39.0 \%, 49.5 \%$ and $21.7 \%$, respectively, and the concentration of $\mathrm{PM}_{2.5}$ can be reduced by $18.2 \%\left(13.3 \mu \mathrm{g} / \mathrm{m}^{3}\right)$. On the basis of CPPs-ICB-ULE, the emission of $\mathrm{NH}_{3}$ was reduced by $30 \%$, the concentrations of ammonium, nitrate and sulfate were reduced by $30.6 \%$, $19.5 \%$ and $46.3 \%$, respectively, and the concentration of $\mathrm{PM}_{2.5}$ was decreased by $16.5 \%$ $\left(12.0 \mathrm{\mu g} / \mathrm{m}^{3}\right)$. With the reduction of $\mathrm{NH}_{3}$ to $50 \%$, the concentrations of ammonium, nitrate and sulfate were decreased by $43.7 \%, 41.7 \%$ and $46.7 \%$, respectively, and the concentration of $\mathrm{PM}_{2.5}$ was decreased by $22.1 \%\left(16.1 \mu \mathrm{g} / \mathrm{m}^{3}\right)$. In conclusion, relative to the $\mathrm{BTH}$ region, the emission of $\mathrm{NH}_{3}$ in the YRD region is higher, severely weakening the reduction effect 
of ULE in CPPs and ICB. After the completion of ULE of CPPs, an $\mathrm{NH}_{3}$ emission reduction by $30 \%$ can achieve a better $\mathrm{PM}_{2.5}$ reduction effect than that of ULE of ICB. Therefore, after the completion of ULE of CPPs, priority should be given to the environmental benefits brought about by $\mathrm{NH}_{3}$ emission reduction, and then to ULE of ICB.

For the SCC region in the CPPs-ULE scenario, as with the $\mathrm{NO}_{\mathrm{x}}$ and $\mathrm{SO}_{2}$ emission reduction, the concentrations of ammonium and sulfate were reduced by $8.8 \%$ and $20.0 \%$, respectively, while the concentration of nitrate increased by $7.5 \%\left(0.8 \mu \mathrm{g} / \mathrm{m}^{3}\right)$, and the concentration of $\mathrm{PM}_{2.5}$ was reduced by $4.6 \%\left(3.2 \mu \mathrm{g} / \mathrm{m}^{3}\right)$. Under the CPPs-ICB-ULE scenario, with the further decrease in $\mathrm{NO}_{\mathrm{x}}$ and $\mathrm{SO}_{2}$, the concentration of ammonium and sulfate decreased by $20.3 \%$ and $42.2 \%$, respectively, while the concentration of nitrate increased by $13.4 \%\left(1.4 \mu \mathrm{g} / \mathrm{m}^{3}\right)$, and the concentration of $\mathrm{PM}_{2.5}$ decreased by $10.4 \%\left(7.2 \mu \mathrm{g} / \mathrm{m}^{3}\right)$. Therefore, relative to the CPPs-ULE scenario, an emission reduction of $\mathrm{NH}_{3}$ by $30 \%$ can significantly reduce the concentrations of nitrate and ammonium, and also reduces the sulfate concentration by $0.3 \%$. This indicates that the atmospheric $\mathrm{NH}_{3}$ emission in the SCC region is insufficient, and $\mathrm{NH}_{4}{ }^{+}$is insufficient to combine with all $\mathrm{SO}_{4}{ }^{2-}$. When the $\mathrm{NH}_{3}$ emission is reduced to $50 \%$, the concentrations of ammonium, nitrate and sulfate can be reduced by $37.2 \%, 59.1 \%$ and $20.4 \%$, respectively, and the concentration of $\mathrm{PM}_{2.5}$ can be reduced by $17.8 \%\left(12.4 \mu \mathrm{g} / \mathrm{m}^{3}\right)$, relative to the STD scenario. On the basis of CPPs-ICBULE, the emission of $\mathrm{NH}_{3}$ was reduced by $30 \%$, the concentrations of ammonium, nitrate and sulfate were reduced by $32.4 \%, 17.4 \%$ and $42.4 \%$, respectively, and the concentration of $\mathrm{PM}_{2.5}$ was decreased by $16.3 \%\left(11.4 \mu \mathrm{g} / \mathrm{m}^{3}\right)$. With the reduction of $\mathrm{NH}_{3}$ to $50 \%$, the concentrations of ammonium, nitrate and sulfate were decreased by $43.3 \%, 45.0 \%$ and $42.5 \%$, respectively, and the concentration of $\mathrm{PM}_{2.5}$ was decreased by $21.7 \%\left(15.1 \mu \mathrm{g} / \mathrm{m}^{3}\right)$. In conclusion, the relative to the YRD region, the emission of $\mathrm{NH}_{3}$ in $\mathrm{SCC}$ region is higher, severely weakening the reduction effect of ULE in CPPs and ICB. After the completion of ULE of CPPs, an $\mathrm{NH}_{3}$ emission reduction by $30 \%$ can achieve a better $\mathrm{PM}_{2.5}$ reduction effect than that of ULE of ICB, and an $\mathrm{NH}_{3}$ emission reduction by $50 \%$ can achieve a better $\mathrm{PM}_{2.5}$ reduction effect than that of ULE of ICB with $\mathrm{NH}_{3}$ emissions reduced by $30 \%$. Therefore, after the completion of ULE of CPPs, priority should be given to the environmental benefits brought about by $\mathrm{NH}_{3}$ emission reduction, and then to ULE of ICB.

For the PRD region in the CPPs-ULE scenario, as with the $\mathrm{NO}_{\mathrm{x}}$ and $\mathrm{SO}_{2}$ emission reduction, the concentrations of ammonium and sulfate were reduced by $11.4 \%$ and $18.8 \%$, respectively, while the concentration of nitrate increased by $1.0 \%\left(0.1 \mu \mathrm{g} / \mathrm{m}^{3}\right)$, and the concentration of $\mathrm{PM}_{2.5}$ was reduced by $6.2 \%\left(2.7 \mu \mathrm{g} / \mathrm{m}^{3}\right)$. Under the CPPs-ICB-ULE scenario, with the further decrease in $\mathrm{NO}_{\mathrm{x}}$ and $\mathrm{SO}_{2}$, the concentrations of ammonium and sulfate decreased by $23.9 \%$ and $40.5 \%$, respectively, while the concentration of nitrate increased by $4.9 \%\left(0.3 \mu \mathrm{g} / \mathrm{m}^{3}\right)$, and the concentration of $\mathrm{PM}_{2.5}$ decreased by $12.7 \%\left(5.6 \mu \mathrm{g} / \mathrm{m}^{3}\right)$. Therefore, relative to the CPPs-ULE scenario, an emission reduction of $\mathrm{NH}_{3}$ by $30 \%$ can significantly reduce the concentrations of nitrate and ammonium, and also reduces the sulfate concentration by $0.2 \%$. This indicates that the atmospheric $\mathrm{NH}_{3}$ emission in the PRD region is insufficient after a $30 \%$ reduction in $\mathrm{NH}_{3}$, and $\mathrm{NH}_{4}{ }^{+}$is insufficient to combine with all $\mathrm{SO}_{4}{ }^{2-}$. When the $\mathrm{NH}_{3}$ emission is reduced to $50 \%$, the concentrations of ammonium, nitrate and sulfate can be reduced by $35.3 \%, 59.7 \%$ and $19.2 \%$, respectively, and the concentration of $\mathrm{PM}_{2.5}$ can be reduced by $17.0 \%\left(7.5 \mu \mathrm{g} / \mathrm{m}^{3}\right)$, relative to the STD scenario. On the basis of CPPs-ICB-ULE, the emission of $\mathrm{NH}_{3}$ was reduced by $30 \%$, the concentrations of ammonium, nitrate and sulfate were reduced by $36.5 \%, 29.5 \%$ and $40.6 \%$, respectively, and the concentration of $\mathrm{PM}_{2.5}$ was decreased by $18.6 \%\left(8.2 \mu \mathrm{g} / \mathrm{m}^{3}\right)$. With the reduction of $\mathrm{NH}_{3}$ to $50 \%$, the concentrations of ammonium, nitrate and sulfate were decreased by $45.3 \%, 53.1 \%$ and $40.6 \%$, respectively, and the concentration of $\mathrm{PM}_{2.5}$ was decreased by $22.7 \%\left(10.1 \mu \mathrm{g} / \mathrm{m}^{3}\right)$.

In conclusion, the emission of $\mathrm{NH}_{3}$ in the PRD region is relatively high, severely weakening the reduction effect of the ULE in CPPs and ICB. After the completion of ULE of CPPs, an $\mathrm{NH}_{3}$ emission reduction by $30 \%$ can achieve the same $\mathrm{PM}_{2.5}$ reduction effect as that of ULE of ICB, and an $\mathrm{NH}_{3}$ emission reduction by $50 \%$ is weaker than that of 
ULE of ICB with $\mathrm{NH}_{3}$ emissions reduced by $30 \%$ for a $\mathrm{PM}_{2.5}$ reduction effect. Therefore, after the completion of ULE of CPPs, the formulation of environmental policies should refer to the BTH region, and the synergistic effect of $\mathrm{NH}_{3}$ emission reduction should be comprehensively considered during the ULE of ICB. Based on the competitive mechanism of sulfate and nitrate, the emission reduction of $\mathrm{NH}_{3}$ makes the $\mathrm{NH}_{3}$ content in the atmosphere change from "surplus" to "insufficient", and the concentration of nitrate is significantly reduced in the process of transformation to ammonia deficiency, followed by the concentrations of ammonium and sulfate, which is consistent with the conclusions of other scholars [50]. $\mathrm{NH}_{3}$ emission reduction converts $\mathrm{NH}_{4} \mathrm{SO}_{4}$ into $\mathrm{NH}_{4} \mathrm{HSO}_{4}$. In addition, $\mathrm{SO}_{2}$ reacts in various ways to form sulfate [48], so, with the increase in the $\mathrm{NH}_{3}$ emission reduction ratio, the sulfate concentration decreases slowly. The main reason for the decrease in the nitrate and ammonium concentrations caused by $\mathrm{NH}_{3}$ emission reduction is the reduction in $\mathrm{NH}_{3}$ available for reaction in the atmosphere and the reduction in precursors of this reaction. Other related chemical reaction mechanisms need to be further studied $[49,51,52]$.

\section{Conclusions}

Although the CPPs have achieved the ULE transformation target, the $\mathrm{PM}_{2.5}$ concentration across the country has decreased by $4.8 \%\left(1.4 \mu \mathrm{g} / \mathrm{m}^{3}\right)$ compared with January 2015, and the haze pollution is still very serious. In addition, ammonium, nitrate and sulfate are important components of $\mathrm{PM}_{2.5}$. Due to the complex non-linear chemical competition mechanism among them, the average concentration of nitrate in the country increases by $1.5 \%\left(0.1 \mu \mathrm{g} / \mathrm{m}^{3}\right)$ under the condition of a large reduction in $\mathrm{NO}_{\mathrm{x}}$ and $\mathrm{SO}_{2}$ emissions, which reduces the environmental benefits of ULE of CPPs. If the ULE technology is applied to the ICB to further reduce $\mathrm{NO}_{\mathrm{x}}$ and $\mathrm{SO}_{2}$, the $\mathrm{PM}_{2.5}$ concentration can be reduced by $10.1 \%$ $\left(2.9 \mu \mathrm{g} / \mathrm{m}^{3}\right)$, and the concentration of nitrate will increase by $2.7 \%\left(0.2 \mu \mathrm{g} / \mathrm{m}^{3}\right)$. Therefore, it is concluded that simply reducing $\mathrm{NO}_{\mathrm{x}}$ and $\mathrm{SO}_{2}$ emissions cannot sufficiently reduce the concentration of $\mathrm{PM}_{2.5}$. Targeted pollutant emission reduction control measures should be formulated according to the specific conditions of different regions to achieve a better reduction in $\mathrm{PM}_{2.5}$ concentration.

Based on the CPPs-ULE, an $\mathrm{NH}_{3}$ emission reduction of $30 \%$ can significantly reduce the concentrations of ammonium and nitrate, so that the $\mathrm{PM}_{2.5}$ concentration decreases by $11.5 \%\left(3.3 \mu \mathrm{g} / \mathrm{m}^{3}\right)$, to achieve a better $\mathrm{PM}_{2.5}$ reduction effect than ULE of ICB. If the $\mathrm{NH}_{3}$ emission reduction reaches $50 \%$, the concentrations of ammonium, nitrate and sulfate can be further reduced, and the $\mathrm{PM}_{2.5}$ concentration can be reduced by $16.5 \%\left(4.7 \mu \mathrm{g} / \mathrm{m}^{3}\right)$. Similarly, based on the CPPs-ICB-ULE, $\mathrm{NH}_{3}$ is reduced by $30 \%$ and $50 \%$, and the $\mathrm{PM}_{2.5}$ concentration is reduced by $15.6 \%\left(4.4 \mu \mathrm{g} / \mathrm{m}^{3}\right)$ and $20.3 \%\left(5.8 \mu \mathrm{g} / \mathrm{m}^{3}\right)$. In summary, $\mathrm{NO}_{\mathrm{x}}$, $\mathrm{SO}_{2}$ and $\mathrm{NH}_{3}$ emission reduction have the same $\mathrm{PM}_{2.5}$ reduction effect. The ULE of CPPs and ICB can reduce $\mathrm{NO}_{x}$ and $\mathrm{SO}_{2}$, thereby reducing the concentrations of ammonium and sulfate, causing the $\mathrm{PM}_{2.5}$ concentration to be reduced, and $\mathrm{NH}_{3}$ reduction is achieved mainly through reducing the concentrations of ammonium and nitrate to reduce the concentration of $\mathrm{PM}_{2.5}$. In order to better reduce the concentration of $\mathrm{PM}_{2.5}, \mathrm{NO}_{\mathrm{x}}, \mathrm{SO}_{2}$ and $\mathrm{NH}_{3}$ emission reduction control measures should be comprehensively considered in different regions of China.

The emission bases of $\mathrm{NO}_{\mathrm{x}}, \mathrm{SO}_{2}$ and $\mathrm{NH}_{3}$ in different regions of China are different, so the changes in regional $\mathrm{PM}_{2.5}$ and its important components under different scenarios are also quite different. For the BTH and PRD regions, after the ULE of CPPs is completed, the synergistic effects of $\mathrm{NH}_{3}$ emission reduction should be comprehensively considered while promoting ULE reduction technologies in the field of ICB. For the YRD and SCC regions, after the completion of ULE of CPPs, priority should be given to the environmental benefits brought about by $\mathrm{NH}_{3}$ emission reduction, and then to the ULE transformation of ICB. In conclusion, in order to reduce $\mathrm{PM}_{2.5}$ more effectively, the economic cost and environmental benefits of emission reduction control measures for $\mathrm{NO}_{\mathrm{x}}, \mathrm{SO}_{2}, \mathrm{NH}_{3}$ and other pollutants should be taken into account comprehensively. 
Supplementary Materials: The following are available online at https:/ / www.mdpi.com/article/10 .3390/atmos12121693/s1, Table S1. Definition of Coal-fired Sectors, Table S2. The Sectors Definition of the GAINS.

Author Contributions: Data curation, J.A.A.; Formal analysis, L.C. and J.W.; Investigation, J.A.A.; Methodology, R.N.; Project administration, S.R. and X.L.; Resources, Y.C.; Software, L.C. and H.W.; Supervision, R.N.; Writing-review \& editing, X.J. All authors have read and agreed to the published version of the manuscript.

Funding: This research was funded by Natural Science Foundation of Shandong Province (ZR2021QD119) and the Fundamental Research Funds for the Central Universities (202113005). The APC was funded by the Strategic Consulting Project of Chinese Academy of Engineering (2021-XY-25).

Institutional Review Board Statement: Not applicable.

Informed Consent Statement: Not applicable.

Data Availability Statement: Not applicable.

Acknowledgments: This research is supported by the Strategic Consulting Project of Chinese Academy of Engineering (2021-XY-25). J.W. is supported by the Natural Science Foundation of Shandong Province (ZR2021QD119) and the Fundamental Re-search Funds for the Central Universities (202113005).

Conflicts of Interest: The authors declare no conflict of interest.

\section{References}

1. MEP Ministry of Environmental Protection of China. Report on the State of Environment in China. 2015. Available online: http:/ / www.mee.gov.cn/gkml/sthjbgw/qt/201606/t20160602_353138.htm (accessed on 10 December 2021).

2. Gao, M.; Beig, G.; Song, S.; Zhang, H.; Hu, J.; Ying, Q.; Liang, F.; Liu, Y.; Wang, H.; Lu, X.; et al. The impact of power generation emissions on ambient $\mathrm{PM}_{2.5}$ pollution and human health in China and India. Environ. Int. 2018, 121, 250-259. [CrossRef] [PubMed]

3. Lelieveld, J.; Evans, J.S.; Fnais, M.; Giannadaki, D.; Pozzer, A. The contribution of outdoor air pollution sources to premature mortality on a global scale. Nature 2015, 525, 367-371. [CrossRef]

4. NAAQS. National Ambient Air Quality Standards: Ambient Air Quality Standards (GB 3095-2012) (Environmental Science Press, Beijing 2011) [R]. The Chinese Ministry of Environmental Protection (MEP). Available online: http://www.gov.cn/hudong/2018 -07/23/5308497/ files/4f9af7c863b149a783f41be590bc4a22.pdf (accessed on 10 December 2021).

5. Ma, J.; Chu, B.; Liu, J.; Liu, Y.; Zhang, H.; He, H. NO promotion of $\mathrm{SO}_{2}$ conversion to sulfate: An important mechanism for the occurrence of heavy haze during winter in Beijing. Environ. Pollut. 2018, 233, 662-669. [CrossRef] [PubMed]

6. Jiao, X.; Liu, X.; Gu, Y.; Wu, X.; Wang, S.; Zhou, Y. Satellite verification of ultra-low emission reduction effect of coal-fired power plants. Atmospheric Pollut. Res. 2020, 11, 1179-1186. [CrossRef]

7. Zheng, B.; Tong, D.; Li, M.; Liu, F.; Hong, C.; Geng, G.; Li, H.; Li, X.; Peng, L.; Qi, J.; et al. Trends in China's anthropogenic emissions since 2010 as the consequence of clean air actions. Atmos. Chem. Phys. Discuss. 2018, 18, 14095-14111. [CrossRef]

8. Cai, S.; Wang, Y.; Zhao, B.; Wang, S.; Chang, X.; Hao, J. The impact of the "Air Pollution Prevention and Control Action Plan" on $\mathrm{PM}_{2.5}$ concentrations in Jing-Jin-Ji region during 2012-2020. Sci. Total Environ. 2016, 580, 197-209. [CrossRef]

9. Tang, L.; Qu, J.; Mi, Z.; Bo, X.; Chang, X.; Anadon, L.D.; Wang, S.; Xue, X.; Li, S.; Wang, X.; et al. Substantial emission reductions from Chinese power plants after the introduction of ultra-low emissions standards. Nat. Energy 2019, 4, 929-938. [CrossRef]

10. Wu, R.; Liu, F.; Tong, D.; Zheng, Y.; Lei, Y.; Hong, C.; Li, M.; Liu, J.; Zheng, B.; Bo, Y.; et al. Air quality and health benefits of China's emission control policies on coal-fired power plants during 2005-2020. Environ. Res. Lett. 2019, 14, 094016. [CrossRef]

11. Ma, Q.; Cai, S.; Wang, S.; Zhao, B.; Martin, R.V.; Brauer, M.; Cohen, A.; Jiang, J.; Zhou, W.; Hao, J.; et al. Impacts of coal burning on ambient $\mathrm{PM}_{2.5}$ pollution in China. Atmos. Chem. Phys. 2017, 17, 4477-4491. [CrossRef]

12. Wang, D.; Hu, J.; Xu, Y.; Lv, D.; Xie, X.; Kleeman, M.; Xing, J.; Zhang, H.; Ying, Q. Source contributions to primary and secondary inorganic particulate matter during a severe wintertime $\mathrm{PM}_{2.5}$ pollution episode in Xi'an, China. Atmos. Environ. 2014, 97, 182-194. [CrossRef]

13. Wang, L.T.; Wei, Z.; Yang, J.; Zhang, Y.; Zhang, F.F.; Su, J.; Meng, C.C.; Zhang, Q. The 2013 severe haze over southern Hebei, China: Model evaluation, source apportionment, and policy implications. Atmos. Chem. Phys. Discuss. 2014, 14, 3151-3173. [CrossRef]

14. Zhang, X.Y.; Wang, J.Z.; Wang, Y.Q.; Liu, H.L.; Sun, J.Y.; Zhang, Y.M. Changes in chemical components of aerosol particles in different haze regions in China from 2006 to 2013 and contribution of meteorological factors. Atmos. Chem. Phys. Discuss. 2015, 15, 12935-12952. [CrossRef]

15. Lang, J.; Zhang, Y.; Zhou, Y.; Cheng, S.; Chen, D.; Guo, X.; Chen, S.; Li, X.; Xing, X.; Wang, H. Trends of PM 2.5 and Chemical Composition in Beijing, 2000-2015. Aerosol. Air Qual. Res. 2017, 17, 412-425. [CrossRef] 
16. Huang, X.; Liu, Z.; Liu, J.; Hu, B.; Wen, T.; Tang, G.; Zhang, J.; Wu, F.; Ji, D.; Wang, L.; et al. Chemical characterization and source identification of PM2.5 at multiple sites in the Beijing-Tianjin-Hebei region, China. Atmos. Chem. Phys. Discuss. 2017, 17, 12941-12962. [CrossRef]

17. Fu, X.; Wang, S.; Xing, J.; Zhang, X.; Wang, T.; Hao, J. Increasing ammonia concentrations reduce the effectiveness of particle pollution control achieved via $\mathrm{SO}_{2}$ and $\mathrm{NO} X$ emissions reduction in east China. Environ. Sci. Technol. Lett. 2017, 4, 221-227. [CrossRef]

18. Liu, M.; Huang, X.; Song, Y.; Tang, J.; Cao, J.; Zhang, X.; Zhang, Q.; Wang, S.; Xu, T.; Kang, L.; et al. Ammonia emission control in China would mitigate haze pollution and nitrogen deposition, but worsen acid rain. Proc. Natl. Acad. Sci. USA 2019, 116, 7760-7765. [CrossRef]

19. Geng, G.; Xiao, Q.; Zheng, Y.; Tong, D.; Zhang, Y.; Zhang, X.; Zhang, Q.; He, K.; Liu, Y. Impact of China's Air Pollution Prevention and Control Action Plan on $\mathrm{PM}_{2.5}$ chemical composition over eastern China. Sci. China Earth Sci. 2019, 62, 1872-1884. [CrossRef]

20. Liu, X.; Gao, X.; Wu, X.; Yu, W.; Chen, L.; Ni, R.; Zhao, Y.; Duan, H.; Zhao, F.; Chen, L.; et al. Updated Hourly Emissions Factors for Chinese Power Plants Showing the Impact of Widespread Ultralow Emissions Technology Deployment. Environ. Sci. Technol. 2019, 53, 2570-2578. [CrossRef]

21. CESY. Department of Energy Statistics, China Energy Statistics Yearbook 2016. Available online: http:/ /www.stats.gov.cn/tjsj/ tjcbw/201706/t20170621_1505833.html (accessed on 10 December 2021).

22. Li, M.; Liu, H.; Geng, G.; Hong, C.; Liu, F.; Song, Y.; Tong, D.; Zheng, B.; Cui, H.; Man, H.; et al. Anthropogenic emission inventories in China: A review. Natl. Sci. Rev. 2017, 4, 834-866. [CrossRef]

23. Rafaj, P.; Amann, M. Decomposing Air Pollutant Emissions in Asia: Determinants and Projections. Energies 2018, 11, 1299. [CrossRef]

24. Saikawa, E.; Kim, H.; Zhong, M.; Avramov, A.; Zhao, Y.; Janssens-Maenhout, G.; Kurokawa, J.I.; Klimont, Z.; Wagner, F.; Naik, V.; et al. Comparison of emissions inventories of anthropogenic air pollutants and greenhouse gases in China. Atmos. Chem. Phys. 2017, 17, 6393-6421. [CrossRef]

25. Kang, Y.; Liu, M.; Song, Y.; Huang, X.; Yao, H.; Cai, X.; Zhang, H.; Kang, L.; Liu, X.; Yan, X.; et al. High-resolution ammonia emissions inventories in China from 1980 to 2012. Atmos. Chem. Phys. 2016, 16, 2043-2058. [CrossRef]

26. Huang, X.; Song, Y.; Zhao, C.; Cai, X.; Zhang, H.; Zhu, T. Direct Radiative Effect by Multicomponent Aerosol over China. J. Clim. 2015, 28, 3472-3495. [CrossRef]

27. Wang, Y.; Li, X.; Yang, J.; Tian, Z.; Sun, Q.; Xue, W.; Dong, H. Mitigating Greenhouse Gas and Ammonia Emissions from Beef Cattle Feedlot Production: A System Meta-Analysis. Environ. Sci. Technol. 2018, 52, 11232-11242. [CrossRef]

28. Chadwick, D.; Wei, J.; Yan'An, T.; Guanghui, Y.; Qirong, S.; Qing, C. Improving manure nutrient management towards sustainable agricultural intensification in China. Agric. Ecosyst. Environ. 2015, 209, 34-46. [CrossRef]

29. Rienecker, M.M.; Suarez, M.J.; Todling, R.; Bacmeister, J.; Takacs, L.; Liu, H.C.; Gu, W.; Sienkiewicz, M.; Koster, R.D.; Gelaro, R.; et al. The GEOS-5 Data Assimilation System: Documentation of Versions 5.0. 1, 5.1. 0, and 5.2. 0. In Technical Report Series on Global Modeling and Data Assimilation, (NASA/TM-2008-104606); NASA: Washington, DC, USA, 2008 ; pp. 1-118.

30. Lin, J.-T.; McElroy, M.B.; Boersma, K.F. Constraint of anthropogenic NOx emissions in China from different sectors: A new methodology using multiple satellite retrievals. Atmos. Chem. Phys. Discuss. 2010, 10, 63-78. [CrossRef]

31. Ni, R.; Lin, J.; Yan, Y.; Lin, W. Foreign and domestic contributions to springtime ozone over China. Atmos. Chem. Phys. Discuss. 2018, 18, 11447-11469. [CrossRef]

32. Fountoukis, C.; Nenes, A. ISORROPIA II: A computationally efficient thermodynamic equilibrium model for $\mathrm{K}^{+}-\mathrm{Ca}^{2+}-\mathrm{Mg}^{2+}-$ $\mathrm{NH}_{4}{ }^{+}-\mathrm{Na}^{+}-\mathrm{SO}_{4}{ }^{2-}-\mathrm{NO}_{3}{ }^{-}-\mathrm{Cl}^{-}-\mathrm{H}_{2} \mathrm{O}$ aerosols. Atmos. Chem. Phys. Discuss. 2007, 7, 4639-4659. [CrossRef]

33. Pye, H.; Liao, H.; Wu, S.; Mickley, L.J.; Jacob, D.J.; Henze, D.K.; Seinfeld, J.H. Effect of changes in climate and emissions on future sulfate-nitrate-ammonium aerosol levels in the United States. J. Geophys. Res. Space Phys. 2009, 114. [CrossRef]

34. Fairlie, T.D.; Jacob, D.J.; Dibb, J.E.; Alexander, B.; Avery, M.A.; van Donkelaar, A.; Zhang, L. Impact of mineral dust on nitrate, sulfate, and ozone in transpacific Asian pollution plumes. Atmos. Chem. Phys. Discuss. 2010, 10, 3999-4012. [CrossRef]

35. Fairlie, T.D.; Jacob, D.J.; Park, R.J. The impact of transpacific transport of mineral dust in the United States. Atmos. Environ. 2007, 41, 1251-1266. [CrossRef]

36. Jaeglé, L.; Quinn, P.K.; Bates, T.S.; Alexander, B.; Lin, J.-T. Global distribution of sea salt aerosols: New constraints from in situ and remote sensing observations. Atmos. Chem. Phys. Discuss. 2011, 11, 3137-3157. [CrossRef]

37. Zhang, H.; Wang, Y.; Hu, J.; Ying, Q.; Hu, X.-M. Relationships between meteorological parameters and criteria air pollutants in three megacities in China. Environ. Res. 2015, 140, 242-254. [CrossRef] [PubMed]

38. He, H.; Wang, Y.; Ma, Q.; Ma, J.; Chu, B.; Ji, D.; Tang, G.; Liu, C.; Zhang, H.; Hao, J. Mineral dust and NOx promote the conversion of $\mathrm{SO}_{2}$ to sulfate in heavy pollution days. Sci. Rep. 2014, 4, 4172. [CrossRef]

39. Park, R.J.; Jacob, D.J.; Field, B.D.; Yantosca, R.M.; Chin, M. Natural and transboundary pollution influences on sulfate-nitrateammonium aerosols in the United States: Implications for policy. J. Geophys. Res. Space Phys. 2004, 109. [CrossRef]

40. Wang, G.H.; Cheng, C.L.; Huang, Y.; Tao, J.; Ren, Y.Q.; Wu, F.; Meng, J.J.; Li, J.J.; Cheng, Y.T.; Cao, J.J.; et al. Evolution of aerosol chemistry in $\mathrm{Xi}^{\prime}$ an, inland China, during the dust storm period of 2013-Part 1: Sources, chemical forms and formation mechanisms of nitrate and sulfate. Atmos. Chem. Phys. Discuss. 2014, 14, 11571-11585. [CrossRef]

41. Zhang, L.; Liu, L.; Zhao, Y.; Gong, S.; Zhang, X.; Henze, D.K.; Capps, S.; Fu, T.-M.; Zhang, Q.; Wang, Y. Source attribution of particulate matter pollution over North China with the adjoint method. Environ. Res. Lett. 2015, 10, 084011. [CrossRef] 
42. Li, M.; Zhang, Q.; Kurokawa, J.-I.; Woo, J.-H.; He, K.; Lu, Z.; Ohara, T.; Song, Y.; Streets, D.G.; Carmichael, G.R.; et al. MIX: A mosaic Asian anthropogenic emission inventory under the international collaboration framework of the MICS-Asia and HTAP. Atmos. Chem. Phys. 2017, 17, 935-963. [CrossRef]

43. Hudman, R.C.; Moore, N.E.; Mebust, A.K.; Martin, R.V.; Russell, A.R.; Valin, L.C.; Cohen, R.C. Steps towards a mechanistic model of global soil nitric oxide emissions: Implementation and space based-constraints. Atmos. Chem. Phys. Discuss. 2012, 12, 7779-7795. [CrossRef]

44. Giglio, L.; Randerson, J.T.; van der Werf, G.R. Analysis of daily, monthly, and annual burned area using the fourth-generation global fire emissions database (GFED4). J. Geophys. Res. Biogeosci. 2013, 118, 317-328. [CrossRef]

45. Guenther, A.B.; Jiang, X.; Heald, C.L.; Sakulyanontvittaya, T.; Duhl, T.; Emmons, L.K.; Wang, X. The Model of Emissions of Gases and Aerosols from Nature version 2.1 (MEGAN2. 1): An extended and updated framework for modeling biogenic emissions. Geosci. Model Dev. 2012, 5, 1471-1492. [CrossRef]

46. Jiao, X.M.; Ren, S.H.; Zhang, W. The promotion of ultra-low emission (ULE) transformation and $\mathrm{NH}_{3}$ emission reduction on the environmental benefits of Beijing-Tianjin-Hebei in winter. Acta Sci. Circumst. 2021. [CrossRef]

47. Liu, X.; Liu, Z.; Jiao, W.; Li, X.; Lin, J.; Ku, A. Impact of "ultra-low emission" technology of coal-fired power on $\mathrm{PM}_{2.5}$ pollution in the Jing-Jin-Ji Region. Front. Energy 2017, 15, 235-239. [CrossRef]

48. Li, X.; Wang, L.; Ji, D.; Wen, T.; Pan, Y.; Sun, Y.; Wang, Y. Characterization of the size-segregated water-soluble inorganic ions in the Jing-Jin-Ji urban agglomeration: Spatial/temporal variability, size distribution and sources. Atmos. Environ. 2013, 77, 250-259. [CrossRef]

49. Cheng, Y.; Zheng, G.; Wei, C.; Mu, Q.; Zheng, B.; Wang, Z.; Gao, M.; Zhang, Q.; He, K.; Carmichael, G.; et al. Reactive nitrogen chemistry in aerosol water as a source of sulfate during haze events in China. Sci. Adv. 2016, 2, e1601530. [CrossRef]

50. Wu, S.Y.; Hu, J.L.; Zhang, Y.; Aneja, V.P. Modeling atmospheric transport and fate of ammonia in North Carolina-Part II: Effect of ammonia emissions on fine particulate matter formation. Atmos. Environ. 2008, 42, 3437-3451. [CrossRef]

51. Lou, Z.G.; Wang, Z.H.; Yang, F. Variation characteristics and source analysis of ammonium salt in typical air pollution processes. Acta Sci. Circumst. 2021, 41, 2577-2583.

52. Liu, X.J.; Sha, Z.P.; Song, Y.; Dong, H.M.; Pan, Y.P.; Gao, Z.L.; Li, Y.E.; Ma, L.; Dong, W.X.; Hu, C.S.; et al. China's Atmospheric Ammonia Emission Characteristics, Mitigation Options and Policy Recommendations. Res. Environ. Sci. 2021, 34, 149-157. [CrossRef] 